\title{
Eocene (Lutetian) Shark-Rich Coastal Paleoenvironments of the Southern North Sea Basin in Europe: Biodiversity of the Marine Fürstenau Formation Including Early White and Megatooth Sharks
}

\author{
C. G. Diedrich \\ PaleoLogic, Nansenstraße 8, D-33790 Halle, Germany \\ Correspondence should be addressed to C. G. Diedrich, cdiedri@gmx.net
}

Received 11 June 2011; Revised 14 August 2011; Accepted 29 August 2011

Academic Editor: Roberto Danovaro

Copyright ( $) 2012$ C. G. Diedrich. This is an open access article distributed under the Creative Commons Attribution License, which permits unrestricted use, distribution, and reproduction in any medium, provided the original work is properly cited.

\begin{abstract}
The Fürstenau Formation (Lutetian, Paleogene, Eocene) is based on type sections near Fürstenau in Germany (central Europe) and is built of 22 meter thick marine glauconitic and strongly bioturbated sands, clays, and a vertebrate-rich conglomerate bed. The conglomerate layer from the Early Lutetian transgression reworked Lower Cretaceous, and Paleogene marine sediments. It is dominated by pebbles from the locally mountains which must have been transported by an ancient river in a delta fan. Marine reworked Lower Cretaceous and Paleogen pebbles/fossils, were derived from the underlying deposits of northern Germany (= southern pre North Sea basin). The benthic macrofauna is cold upwelling water influenced and non-tropical, and medium divers. The vertebrate fish fauna is extremely rich in shark teeth, with about 5,000 teeth per cubic meter of gravel. The most dominant forms are teeth from sand shark ancestors Striatolamia macrota, followed by white shark ancestors Carcharodon auriculatus. Even teeth from the magatooth shark ancestor Carcharocles sokolovi are present in a moderately diverse and condensed Paleogene fish fauna that also includes rays, chimaeras, and more then 80 different bony fish. Fragmentary turtle remains are present, and few terrestrial vertebrates and even marine mammals with phocids, sirenians and possibly whales.
\end{abstract}

\section{Introduction}

Early research in the Dalum fossil locality in the Fürstenau region of north-west Germany (Figure 1(a)) concentrated largely on the stratigraphy and the fossil shark tooth content [1]. A preliminary analysis of the conglomerate components has also been published by Bartholomäus [2]. The site has only been excavated by private collectors, who have been active there since 1971 [2]. Whereas aragonite and calcite fossils at Dalum have all been dissolved away, they are still preserved in a sand pit at Osteroden (Figure 1(b)) from which 11,000 fish otoliths have previously been analysed by Schwarzhans [3]. The extremely rare teeth of terrestrial mammals from the Dalum and Osteroden sites were the focus of a paper by Franzen and Mörs [4].

The Paleogene (Middle Eocene) marine localities at Dalum and Osteroden (Figures 1(a) and 1(b)), in the south- ern pre-North Sea basin, represent an important environmental bridge between marine, coastal, deltaic swamp, and terrestrial faunas (Figure 1(c)). The marine-dominated fossils at Dalum also offer valuable information on the paleobiodiversity of the central European tropical terrestrial faunas during the Eocene.

Other important marine Eocene sites in Europe are at Helmsleben in Germany, and at Oosterzele and Balegem in Belgium (Figure 1(c)), which are also well known for their enormous quantities of shark teeth [5] and which also contain rare remains of terrestrial mammals [4]. The marine Paris Basin to the south of the Artois submarine swell (Figure 1(c)) is also one of the classic fossil regions of Europe in which many of the shark species presented herein were first found, as described in the monograph by Lériche [6], as well as by other authors. Finally, the Lower Eocene London Clay Formation in England, for example, on the Isle of Sheppey 


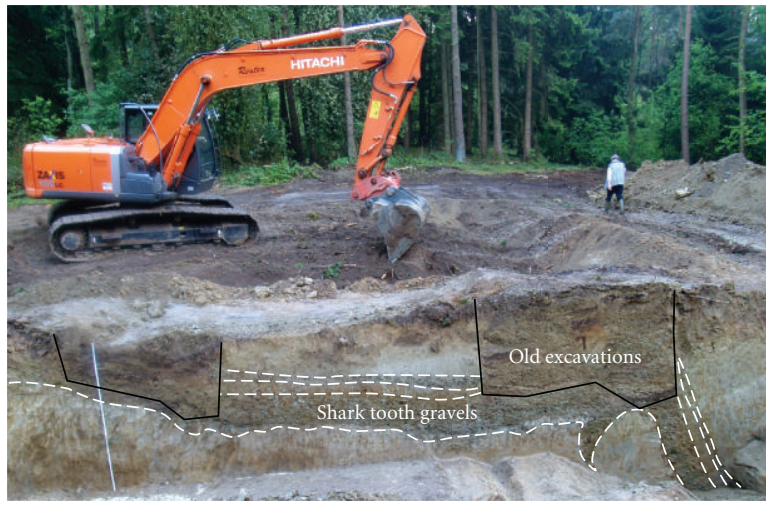

(a)

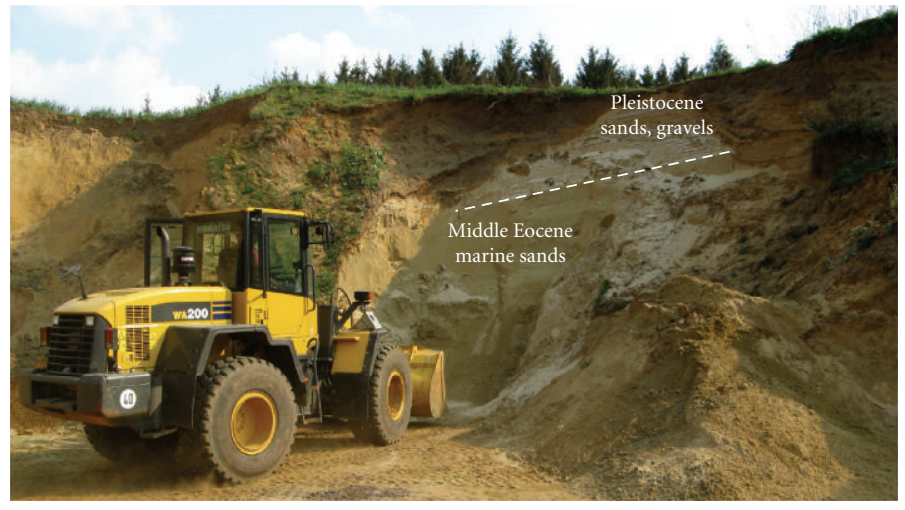

(b)

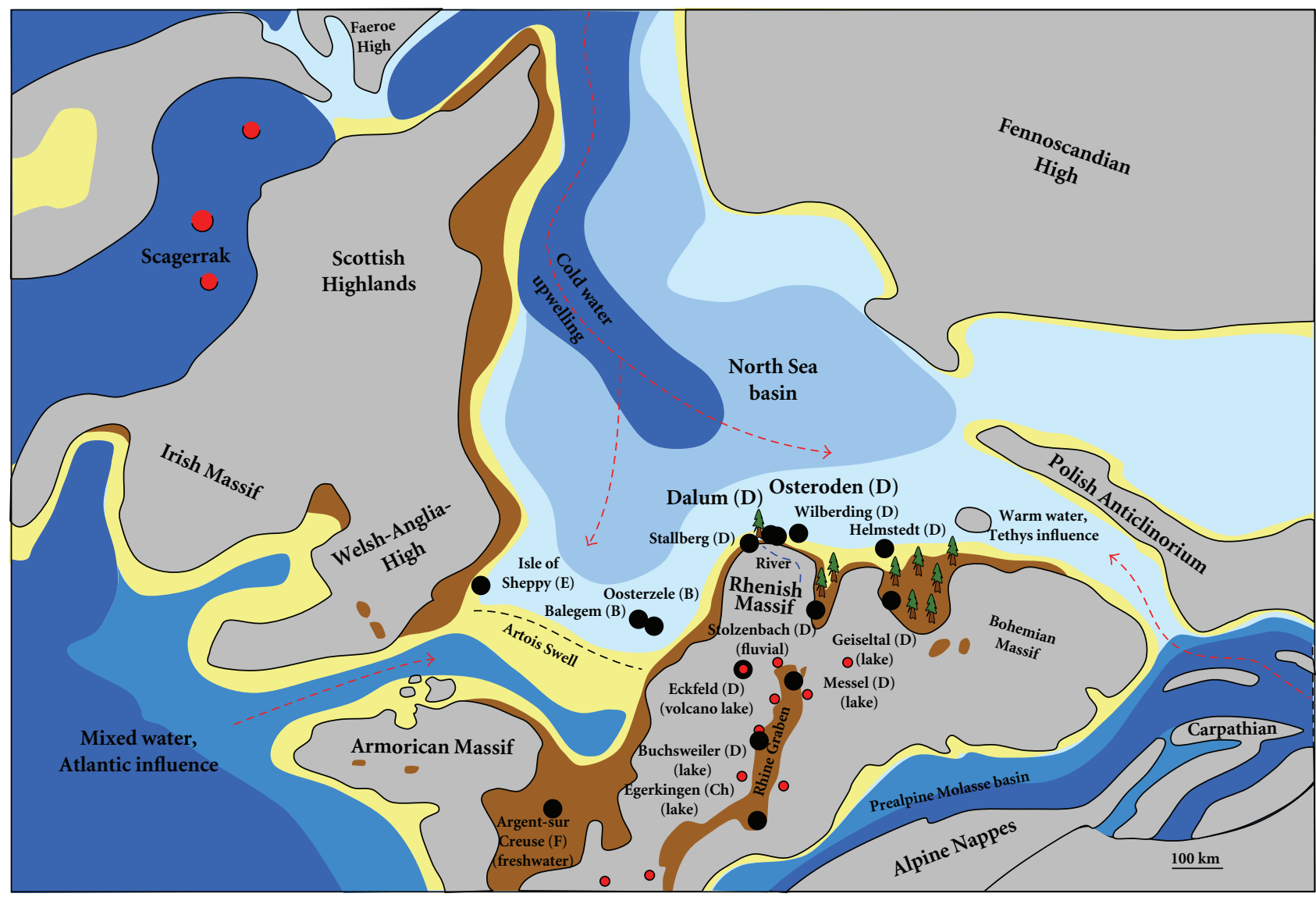

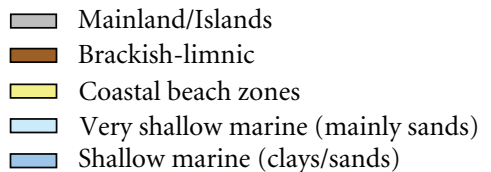

$\square$ Mainland/Islands

$\square$ Coastal beach zones

$\square$ Shallow marine (clays/sands)

Figure 1: (a) The Dalum site near Fürstenau and (b) the Osteroden sand pit near Bippen, in north-western Germany. (c) Paleogeography of important Eocene marine and terrestrial vertebrate fossil sites of Europe (compiled from [4, 5, 9-14]). 
(Figure 1(c)), represents near-shore, fresh-water-influenced, coastal paleoenvironments that contain overlapping terrestrial and marine faunal remains [7].

The Eocene terrestrial fauna (Figure 1(c)) was made famous by the abundance of early mammal, bird, reptile, anuran, and fish skeletons, as well as botanical specimens and insects, from the German at UNESCO World Heritage Messel sites at Geiseltal (an Early to Middle Eocene lake site) [8] and at Messel (Middle Eocene) [9]. The Eckfeld Maar volcano lake site has also yielded important fossil material of terrestrial fauna and flora from the Middle Eocene [10], as have the Eocene coal mine at Stolzenbach [11] and the Swiss mammal site at Egerkingen, which is of Upper Eocene of age [12].

This study presents preliminary stratigraphic and sedimentological analyses focussed on the marine, terrestrially influenced, vertebrate-rich gravels at Dalum, and includes a preliminary statistically based overview of the site with regard to the quality and quantity of its fossils. This information is used for a paleoenvironmental reconstruction resulting in the compilation of a new paleogeographical map, and to provide an overview of the (mainly marine) biodiversity, and marine palaeocurrents on the southern pre North Sea basin.

\section{Material and Methods}

In May and June of 2011 the UNESCO-supported "Geo and Naturpark TERRA.Vita" near Osnabrück (NW Germany) started a systematic excavation and research project (under the leadership of the PaleoLogic private research institute) at the Dalum forest site near Fürstenau (Figure 1(a)) and at a second locality in the Osteroden sand pit, Bippen (Figure 1(b)). The eventual objective, following the completion of the research program, was to develop and promote the Shark Center at Bippen, which is a visitor and research center within the UNESCO-supported "Geo and Naturpark TERRA.Vita" of north-west Germany.

In May 2011 a 4-day field program using heavy machinery was completed at the Dalum and Osteroden sites (Figures $1(\mathrm{a})$ and 1(b)). Stratigraphic cross-sections were prepared at both of these sites (making use of 5-meter drillholes at Osteroden) indicating a combined 22-meter thick marine section (Figure 3).

A total of 180 cubic meters of conglomeratic material was excavated from the Dalum site for sieving, of which only 250 buckets (10 litres each) were sieved during the following two weeks (i.e., only $0.1 \%$ of the recovered material). It was only possible to excavate 10 cubic meters of material at the Osteroden site, which has not yet been sieved (other than for a preliminary sample) because of the intense weathering and damage shown by all of the fossils, and the large degree of root dissolution in the teeth.

Attention has therefore been focussed on the Dalum gravel, which was sieved into two different fractions of $+4 \mathrm{~mm}$ and -4 to $+1 \mathrm{~mm}$, in order to obtain a good variety of gravel types (Figures 4-5), invertebrate remains (Figures 6-8), and vertebrate remains (Figures 9-15), and to facilitate the gravel pebble analysis. Only material greater then $4 \mathrm{~mm}$ is presented herein, which is adequate for qualitative and quantitative gravel analyses and for analysis of the main vertebrate fauna. In total, 14,437 fossils were recovered and studied, of which 95\% are shark teeth and only 5\% (747 specimens) are teeth from other types of animals (Figure 5).

More than half of the 13,683 shark teeth recovered were identifiable, but lower proportions of the ray teeth and fin spines and the bone fish teeth and bones. The finer material (less than $4 \mathrm{~mm}$ ) appears (after sieving a preliminary sample) to contain many additional species, which will be recovered and examined during the coming years from the retained fine fraction of the gravel. A separate, more detailed fish analysis (covering all material $>1 \mathrm{~mm}$ ) will also be the subject of future research, after much more material has been recovered to allow a more complete picture of the fish and invertebrate paleobiodiversity in the pre-North Sea basin during the Eocene.

All the material described and illustrated herein from the 2011 excavations (14,440 fossils in total) is now housed in the Shark Center, Bippen (SCB).

\section{Geology and Sedimentology}

3.1. Glacial Tectonics. The Tertiary sediments in north-west Germany were deformed and compressed as a result of Middle Pleistocene glacial tectonics [13]. The Ankumer range in particular is the result of proglacial folding due to a Saalian glacier, as indicated by a U-shaped moraine that extends as far as the north-western part of the Wiehengebirge mountain range near Bramsche (Figure 2(a)) [15]. The Eocene sediments at the Dalum (Figure 2(c)) and Osteroden sites are therefore strongly folded. The fold axis at Dalum is oriented east to west (parallel to the main glacial fold axis, cf. Figure 2(c)), with a "saddle" that dips at about 10-15 towards the east. In a road cutting about 50 meters to the east of the new sampling trench and parallel to it (Figure 2(c)) the top of the saddle structure is missing in the road section [1] having been eroded during the Saalian and further the Weichselian Ice Age. At the new section in the forest instead the top of the saddle is preserved and the convex deformed sediment layers that would normally be expected are more or less horizontal (Figure 2(c)), indicating that the saddle has been compressed from above. At Osteroden the deformation is more complex, and in the recent pit the gravel layers dip at about $30-60^{\circ}$ to the north-east. This is also parallel to the main axis of glacial deformation (Figure 2(a)).

3.2. Paleogene Stratigraphy, Sedimentology, and Dating in North-West Germany. No firmly dated early Tertiary (Paleocene) deposits are known in north-west Germany [13].

Early Eocene (Ypresian) marine sediments have, however, been dated by microfossils such as diatoms, radiolarians, and foraminifers $[16,17]$, and are known from a clay pit at Wilberding, near Damme in north-west Germany [18], and also from another clay pit at Stallberg near Emsbüren (Figure 1(c)) which contains shark remains and reworked iron-carbonate concretions from the Lower Cretaceous [19]. These gray-green, glauconitic marine clays of Wilberding and 

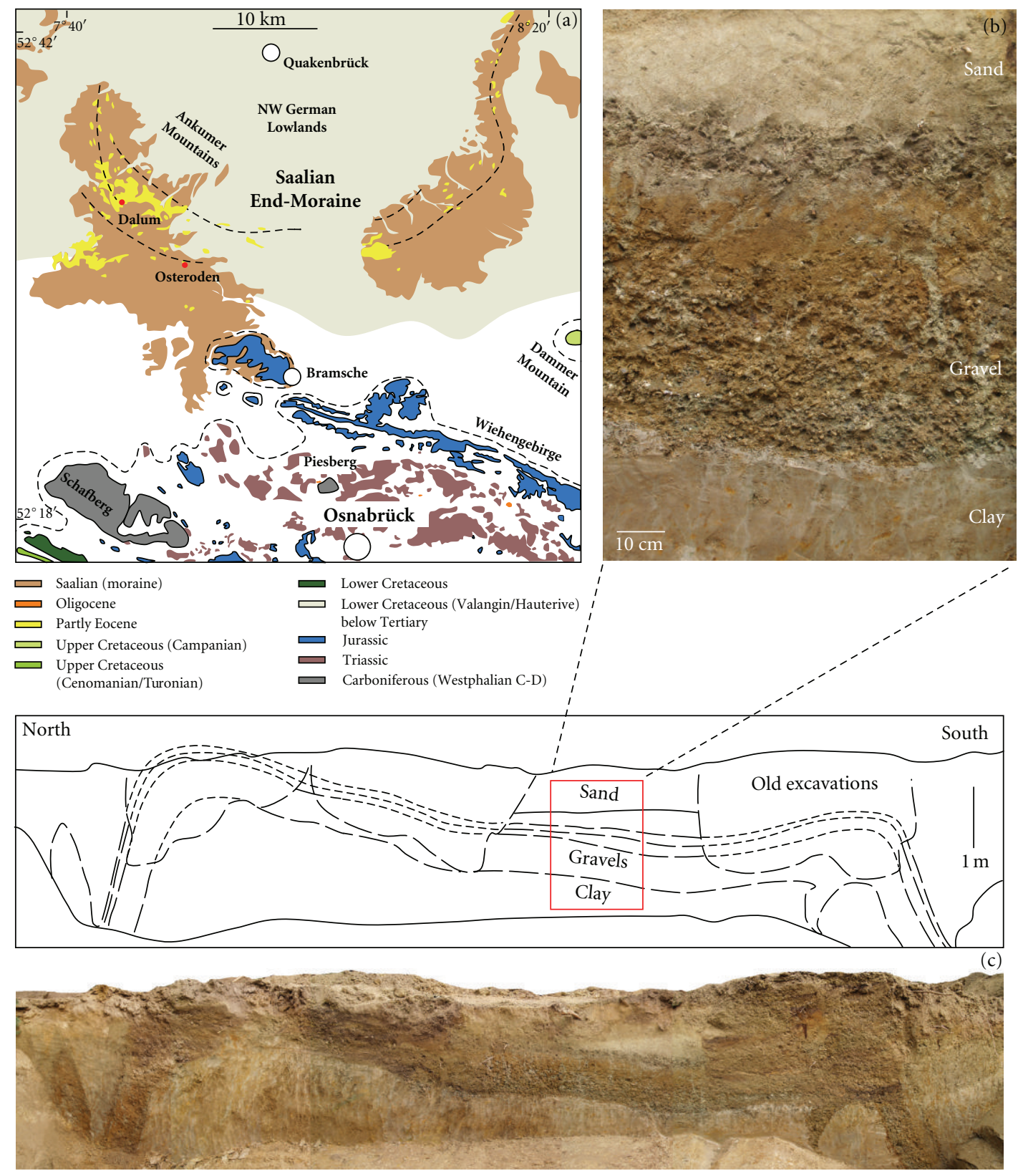

FIGURE 2: Glacial tectonics and distribution of Tertiary deposits as result of (a) the Saalian Ice Age end-moraine forming the Ankumer Mountains (geology redrawn and simplified from [15]), including the Eocene sites at Dalum and Osteroden; (b) north-south section through the gravels at Dalum; (c) photo of the same section at Dalum, showing the Eocene marine deposits, which where deformed into a saddle-like structure (well visible in the Eocene gravel layer) by glacial compression.

Stallberg containing phosphorite nodules (phosphorites), that appear to be of Lower Eocene age, represent the earliest known marine Tertiary sediments in north-west Germany. The Stalberg section also contained many mixed layers $1 \mathrm{~mm}$ to $40 \mathrm{~mm}$ thick of volcanic ash (tuff) and marine sediments, which are explained as being the result of volcanic ash clouds from the marine strait Skagerrak (possibly also from the Eifel volcanos, e.g., the Eckfelder Maar, cf. Figure 1(c)) [20]. This was a tectonically active period that was also responsible for the Rhine Graben structure of central Europe
(Figure 1(c)) [20], and it was also the time when the Messel and Geiseltal fossil sites were formed in Germany, together with the Stolzenbach site and the coastal swamps of the Rhenish Massif (Figure 1(c)).

Middle Eocene (Lutetian) marine deposits for the Dalum and Osteroden sites are presented herein, and a new formation name introduced. A compilation of the two sections from Dalum and Osteroden (Figure 3) has allowed the dating of these sediments, and also enabled sedimentological and paleoenvironmental interpretations to be made. 


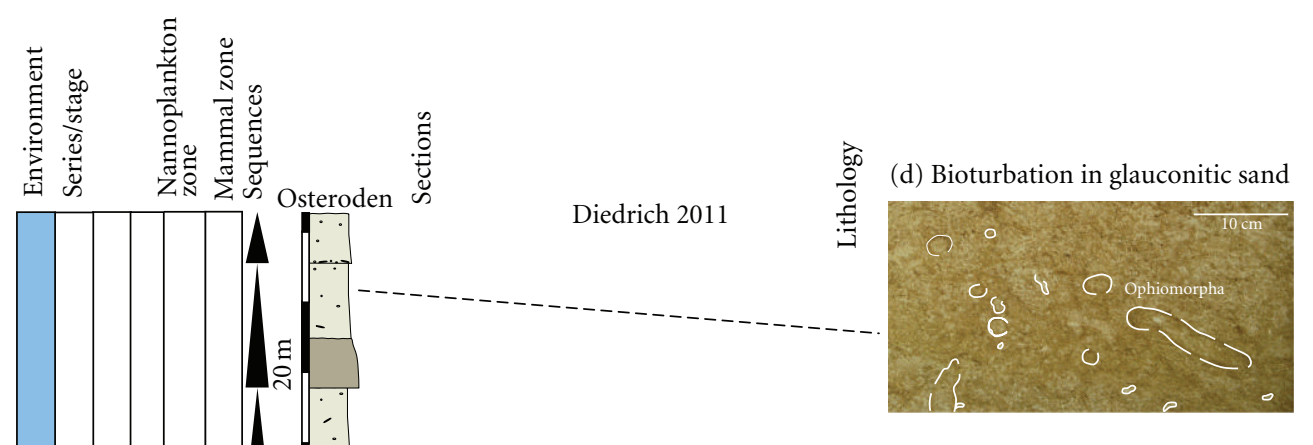

(c) Light-green to brown fine-grained, clayey sand

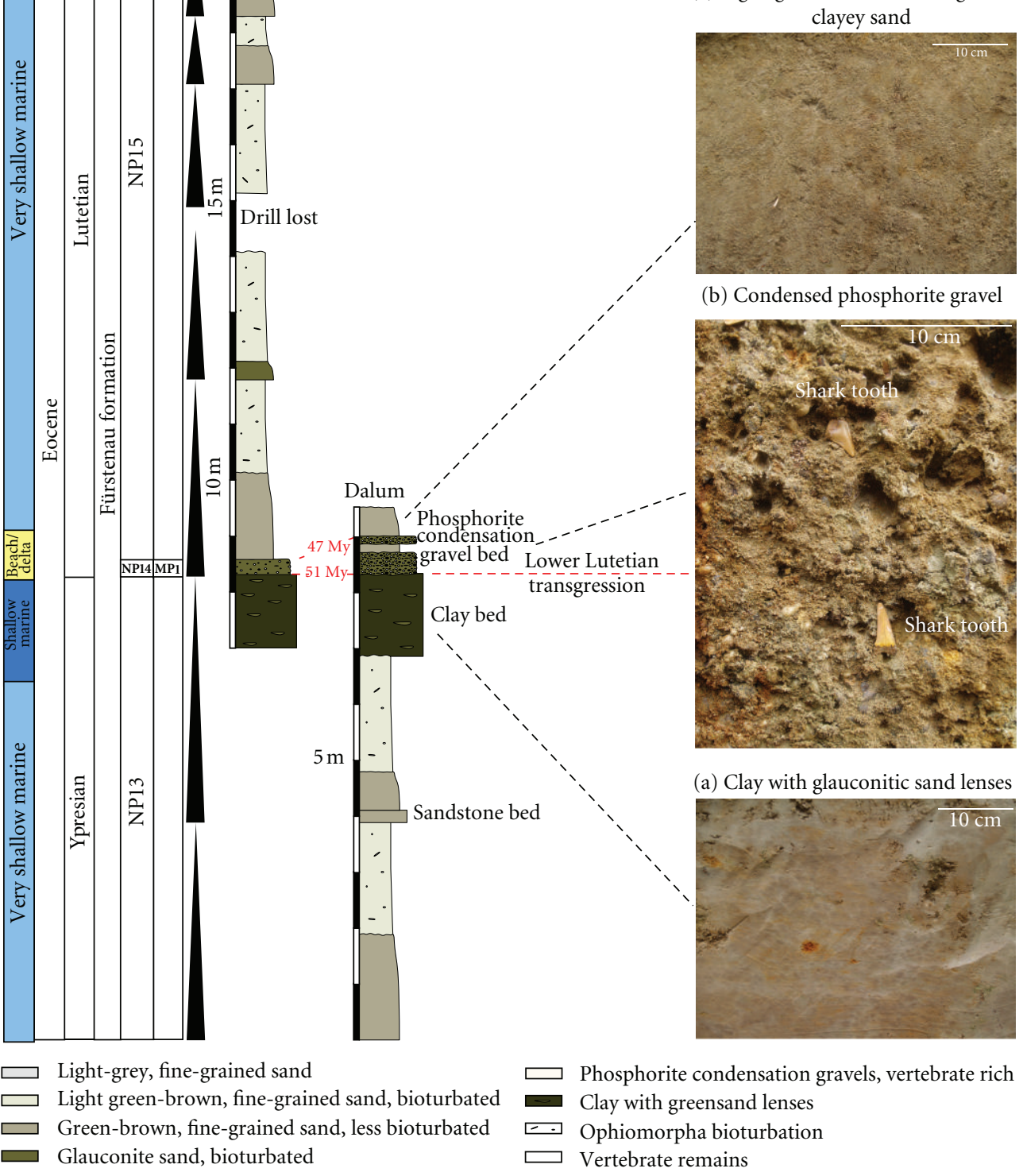

(b) Condensed phosphorite gravel

FigURE 3: Stratigraphy and sedimentology of the Eocene Fürstenau Formation vertebrate sites at Osteroden and Dalum (NW Germany). (a) Clay with glauconitic sand lenses. (b) Condensed phosphorite gravel bed with abundant vertebrate remains, especially shark teeth. (c) Light-green to brown fine-grained, clayey sand, at the base of the sequence. (d) Bioturbated glauconitic sands, with Ophiomorpha and other burrows (top of sequence). 


\subsection{The New "Fürstenau Formation" (Ypresian to Lutetian, Early to Middle Eocene)}

3.3.1. Type Stratum. Fürstenau Formation, Early to Middle Eocene, after the nearby city of Fürstenau.

3.3.2. Type Localities. The Dalum site near Fürstenau and the Osteroden sand pit near Bippen, north-west Germany.

3.3.3. Description. The Fürstenau Formation is exposed over a thickness of about 22 meters (Figure 3), the lower part of which (Early Eocene, Ypresian) consists of slightly glauconitic marine sands, with thinly bedded sandstone layers above (Dalum site). These are followed by 1 to 2 meters of thick gray-green clays with lenses of glauconitic sand (possibly still Early Eocene), the top of which have been eroded by a conglomerate bed $40 \mathrm{~cm}$ thick at Osteroden and $80 \mathrm{~cm}$ thick at Dalum (Figure 2(b)). These conglomerates can be dated herein into the basal Lutetian (basal Middle Eocene). They are fully decalcified at Dalum but are carbonatic at Osteroden where they contain calcareous shells of marine invertebrates, as well as aragonitic fish otoliths in places. The middle Middle Eocene marine glauconitic sands (NP 15 Zone) are composed of at least seven parasequence sets, starting with green, clay-rich, fine-grained sands and ending with greengray, glauconitic, highly bioturbated (mainly Ophiomorpha), medium-grained sands (Figures 3, 7(1-3)). The gravels and the macrofauna from the Fürstenau Formation are described below.

\section{Analysis of the Condensed Lutetian Phosphorite Conglomerate Bed}

4.1. Pebble Types and Origin. The degree of rounding in the pebbles varies (Figure 4), but this property is not very useful for the Carboniferous quartzite pebbles as they are rederived Paleozoic fluvial clasts that were already rounded. Further analysis of the degree of rounding and estimates of transport distances are therefore unlikely to succeed, at least for that particular fraction of the pebbles.

Other pebble groups such as most of the flint pebbles, however, do indicate long-distance transport over a long period of time within a marine environment, while those comprised of local sediments, especially carbonates, have clearly only travelled relatively short distances.

The qualitative rock analysis reveals more then 30 different types of rock within the conglomerates from Dalum and Osteroden (Figure 4), for which provenances cannot always be determined. It has, however, been possible to identify the main rock types and their original ages (Table 1) which are important for an understanding of terrestrial or limnic influences, marine paleocurrents, and the erosional history of the region, and have allowed a new paleogeographical map to be drawn up (Figure 5).

4.1.1. Paleozoic Sedimentary Clasts. Clear to white and pale red or milky, well-rounded quartz pebbles (Figures $4(1)$ and $4(4))$ are from the Westphalian C-D sandstone series
TABLE 1: Dalum gravel analysis based on 3,927 pebbles $(>4 \mathrm{~mm})$.

\begin{tabular}{|c|c|c|}
\hline Age & Rock type & $\begin{array}{l}\text { Number } \\
\text { of clasts }\end{array}$ \\
\hline \multirow[t]{5}{*}{$\begin{array}{l}\text { Paleogene (Early/Middle } \\
\text { Eocene) }\end{array}$} & Phosphorite concretions & 600 \\
\hline & Phosphorite burrows & 1 \\
\hline & Phosphorite fossils & 1 \\
\hline & $\begin{array}{l}\text { Fine-grained white } \\
\text { sandstone }\end{array}$ & 10 \\
\hline & $\begin{array}{l}\text { Vertebrate remains } \\
\text { (mainly shark teeth) }\end{array}$ & 150 \\
\hline $\begin{array}{l}\text { Upper Cretaceous } \\
\text { (Campanian-Maastrichtian) }\end{array}$ & Flint & 10 \\
\hline \multirow[t]{3}{*}{$\begin{array}{l}\text { Lower Cretaceous } \\
\text { (Valanginian-Hauterivian) }\end{array}$} & $\begin{array}{l}\text { Iron-carbonate concretion: } \\
\text { rock fragments }\end{array}$ & 980 \\
\hline & $\begin{array}{l}\text { Iron-carbonate concretion: } \\
\text { burrows }\end{array}$ & 50 \\
\hline & $\begin{array}{l}\text { Iron-carbonate concretion: } \\
\text { ammonite fragments }\end{array}$ & 10 \\
\hline \multirow[t]{3}{*}{$\begin{array}{l}\text { Jurassic } \\
\text { (Bathonian-Kimmeridgian) }\end{array}$} & Oolitic iron ores & 1 \\
\hline & Oolitic carbonates & 1 \\
\hline & $\begin{array}{l}\text { Silica-iron-carbonate } \\
\text { concretions }\end{array}$ & 1 \\
\hline \multirow[t]{2}{*}{$\begin{array}{l}\text { Carboniferous (Westphalian } \\
\text { C-D) }\end{array}$} & Quartzite & 2,100 \\
\hline & Quartzite conglomerates & 10 \\
\hline Devonian & Black lydite & 1 \\
\hline Volcanic rocks (age unclear) & Red volcanic rocks & 1 \\
\hline
\end{tabular}

of the Upper Carboniferous, which outcrops mainly within the Schafberg horst structure, but also at the lesser extent Piesberg and Hüggel horsts near Osnabrück [21]. These quartzite pebbles were already well rounded by previous transport during the Paleozoic and similar well-rounded quartzite pebbles can be seen in the conglomerates of the Piesberg and Schafberg horsts. These pebbles have therefore been redeposited after travelling only short distances, and do not provide any evidence of long-distance transport during the Paleogene, to their secondary deposition site.

4.1.2. Paleozoic Volcanic Clasts. Clasts of red volcanic rocks (Figures $4(11-12))$ are only present as small pebbles $(<3 \mathrm{~cm})$ and their origin remains unclear. They were probably carried southwards from the Fennoscandian High by upwelling currents, because no such volcanic rock types are known to the south in the northern Rhenish Massif.

4.1.3. Lower Cretaceous Reworked Fossils and Clasts. The most abundant reworked fossils are ammonite fragments (Figures 4(27) and 4(31)), especially single chambered fragments (see the "cat paw" specimen in Figure 4(28)), which are all found in carbonate-iron concretions that originated from the Lower Cretaceous claystones of northern Germany. Most abundant are fragments of orthicon ammonites (Figures $4(27)$ and $4(28))$. 

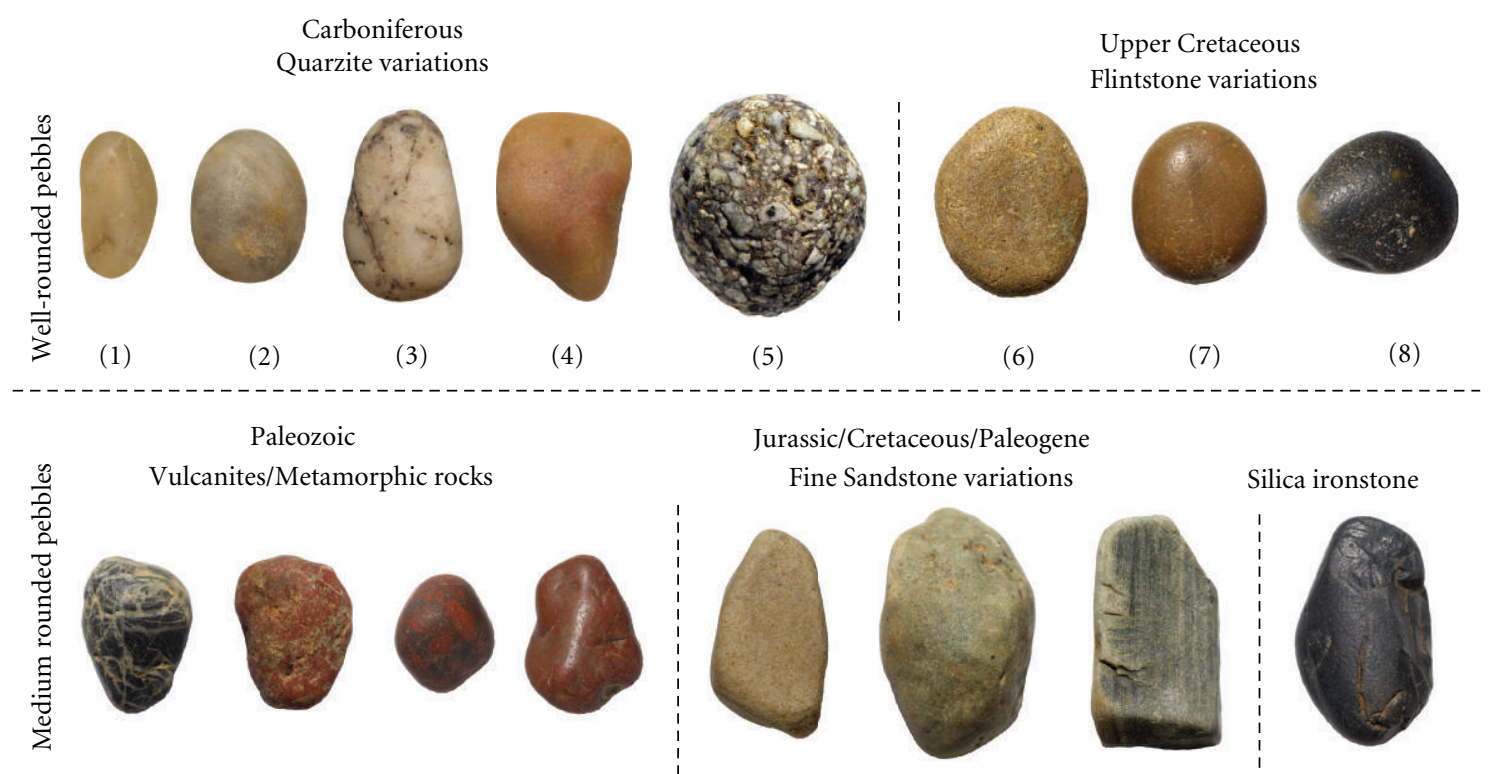

Paleozoic

(9)
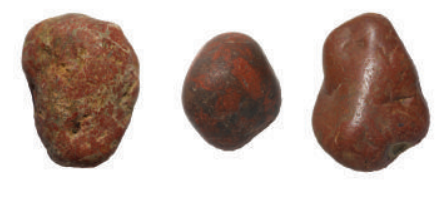

(10)

(11)

(12)

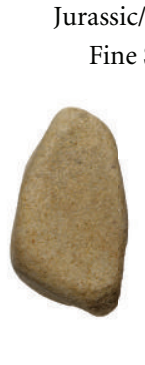

(13)
Cretaceous/Paleogene

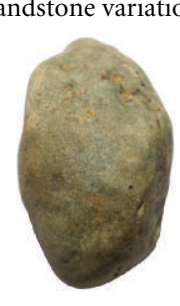

(14)

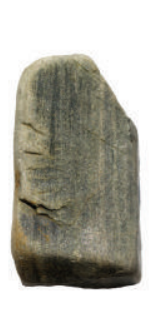

(15)

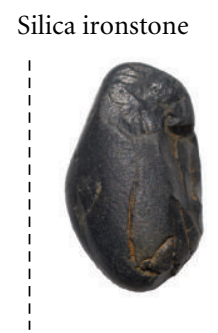

(16)

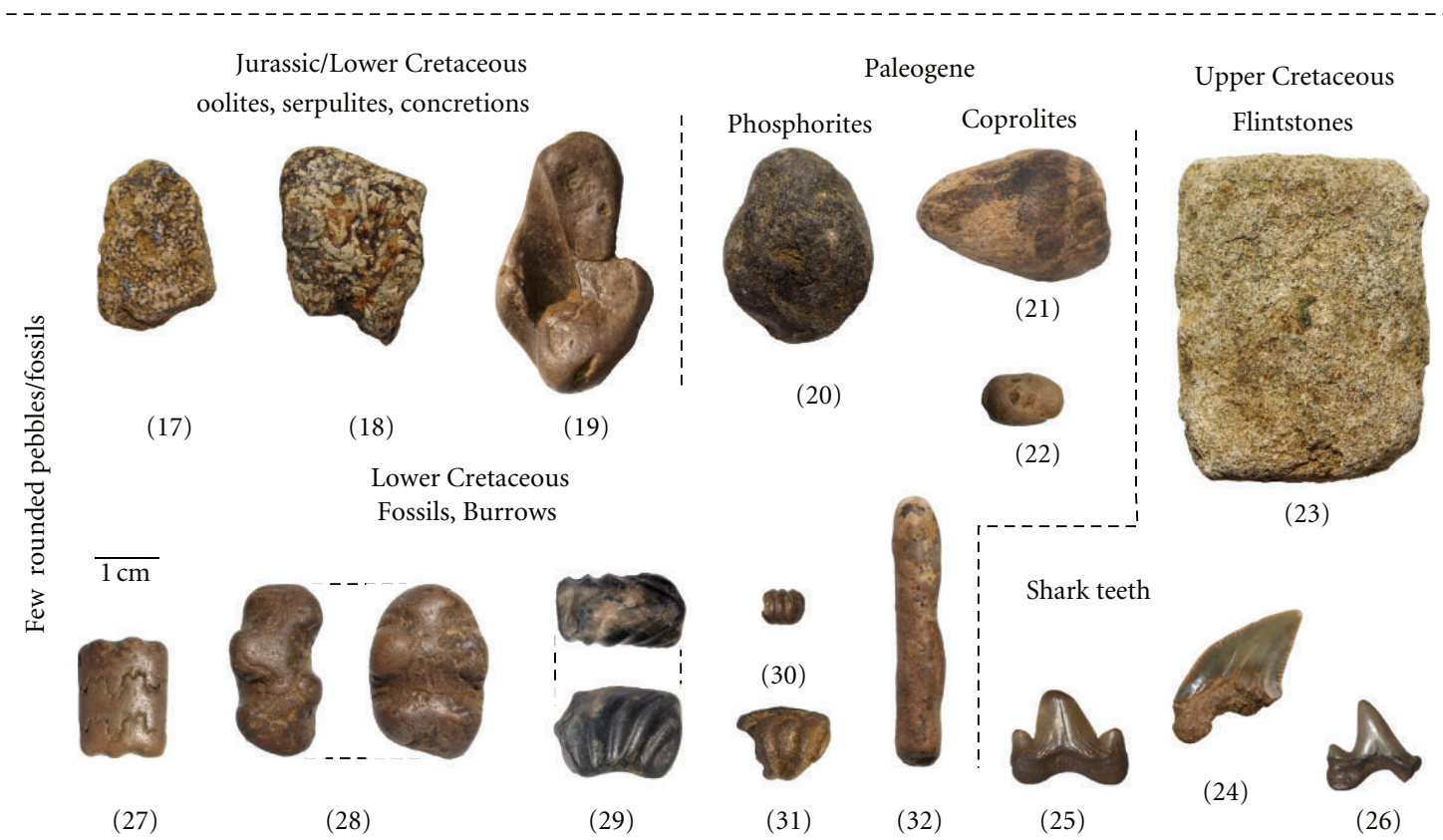

FIgURE 4: Middle Eocene (basal Lutetian) gravel types. (1-3(?4)) Carboniferous (Westphalian C-D, originating from the Schafberg and Piesberg mountains) quartzite variants which were already well rounded in the Paleozoic, and have only been transported a short distance since then (SCB no. Sedim-2). (5) Carboniferous conglomerate (Westphalian C-D), originating from the Schafberg and Piesberg mountains (SCB no. Sedim-3). (6-8) Upper Cretaceous (Campanian-Maastrichtian) flints (SCB no. Sedim-6), consisting of Campanian "Rijckholt" flint (6-7) from the Aachen region and northern Netherlands (SCB no. Sedim-6a) and "Maas-Egg," black flint (8) from the Maastrichtian of the northern Netherlands (SCB no. Sedim-6b). (9) Paleozoic metamorphite of uncertain origin (SCB no. Sedim-10), (10-12) red Paleozoic volcanic rocks of uncertain origin, possibly from Scandinavia (SCB no. Sedim-13), (13) Paleogene white fine-grained sandstone of uncertain origin (SCB no. Sedim-9), (14-15) Paleogen glauconitic fine-grained sandstones (SCB no. Sedim-11), and (16) Jurassic silica/iron-carbonate concretion from the Osnabrücker Bergland (SCB no. Sedim-17). (18) Jurassic or Lower Cretaceous serpulid (SCB no. Sedim-4). (19) Ironcarbonate concretion fragment with orthicon (Bochianites) ammonite negatives from the Valanginian/Hauterivian, Lower Cretaceous (SCB no. Sedim-18). (20) Middle Eocene phosphorite nodule (SCB no. Sedim-7). (21-22) Eocene phosphatic shark coprolites (SCB no. Sel-890, 898). (23) Upper Cretaceous (Campanian) platy flint (SCB no. Sedim-8). (24) Shark tooth from Squalicorax kaupi, reworked from the Campanian, Upper Cretaceous (SCB Dal-Sel-901), labial. (25) Shark tooth from Cretolamna appendiculata, reworked from the SantonianCampanian, Upper Cretaceous (SCB Dal-Sel-882), labial. (26) Shark tooth from Cretolamna appendiculata, reworked from the Campanian, Upper Cretaceous (SCB Dal-Sel-881), labial. (27) Lower Cretaceous (Upper Valanginian) orthicon ammonite fragment of (Bochianites sp. (SCB no. Sedim-18). (28) Lower Cretaceous (Upper Valanginian) orthicon ammonite fragment, a so-called "cat paw" (SCB no. Sedim-17). (29) Lower Cretaceous (Lower Hauteriveian) ammonite fragment of Endemoceras sp. (SCB no. Sedim-22). (30) Lower Cretaceous (Upper Hauteriveian) ammonite fragment of Aegocrioceras sp. (SCB no. Sedim-22). (31) Lower Cretaceous (Upper Valanginian) ammonite fragment of Oostrella sp. (SCB no. Sedim-18). (32) Lower Cretaceous elongated burrow preserved in iron-carbonate concretion (SCB no. Sedim-43). 

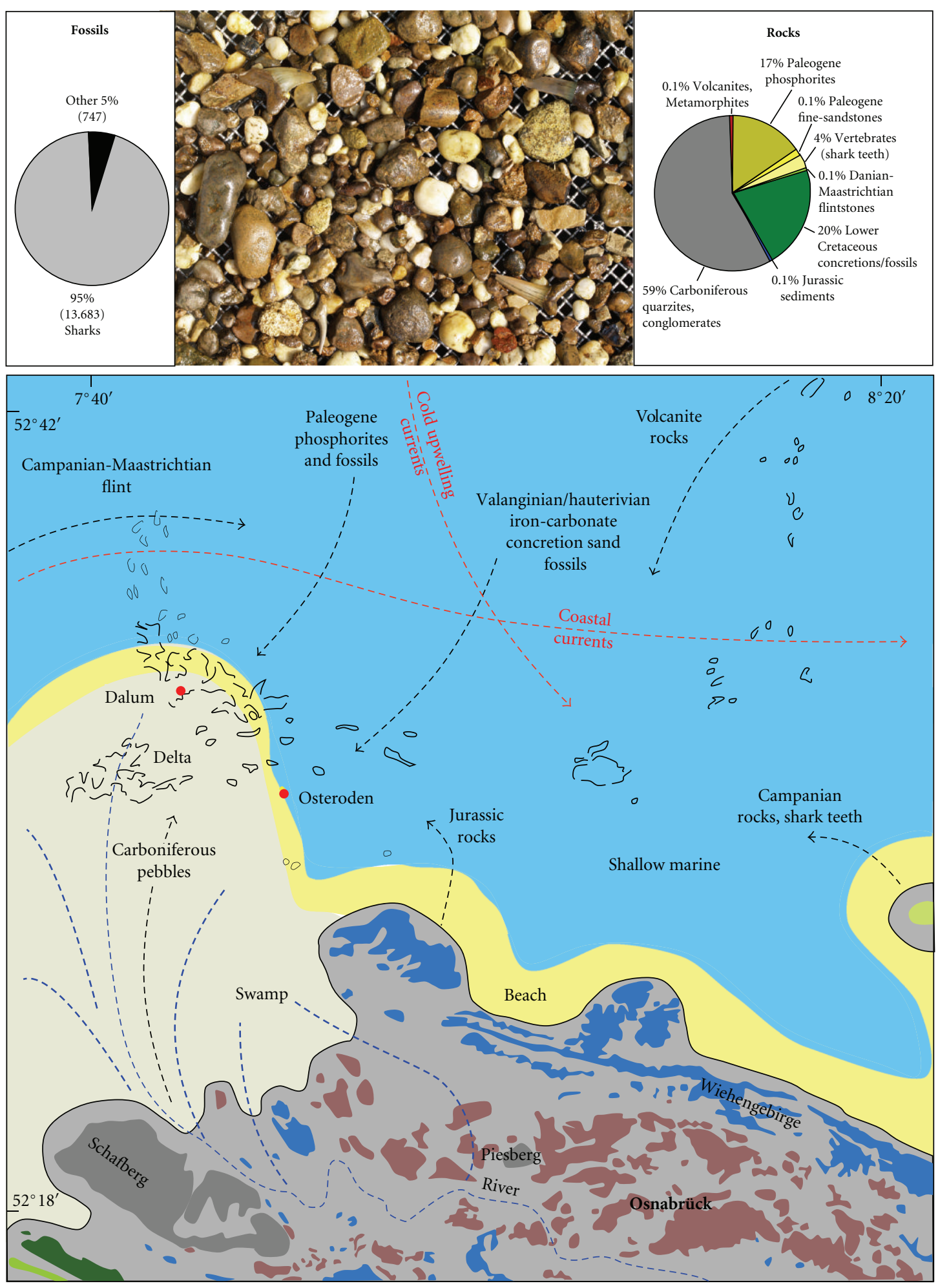

Figure 5: Basal Middle Eocene (Early Lutetian) gravel: quantitative analysis and transportation direction reconstruction. The main Paleozoic components (Carboniferous quartz) must have been transported by an ancient river running between today's Wiehengebirge and Teutoburger Wald mountain ranges, ending in a delta. Other components (Jurassic material) are from the Wiehengebirge range, whereas Lower Cretaceous pebbles and ammonite fossils are from north Germany. Flints were accumulated from different directions (Maastricht/Aachen area, and Dammer Berge; Material no. SCB Dal-Sedim-1-16). 
The ammonite fragments, which are also found in the Lower Cretaceous claystones of north-west Germany [22], range in age from Valanginian to Hauterivian (Lower Cretaceous) and include Bochianites sp. and Oosterella sp. (Upper Valanginian), Endemoceras sp. and Leopoldia sp. (Lower Hauterivian), and Aegocrioceras sp. (Upper Hauterivian). All ammonites must have already been previously reworked during the Lower Eocene [19], and again during the basal Middle Eocene transgression. Rock types with similar (mediumbrown) preservation to these reworked fossils contain abundant fossilized burrow casts (Figure 4(32)) and must have originated from the Lower Cretaceous marine sediments of north-west Germany. These can be distinguished from Eocene burrow casts since the latter are different and occur in phosphatic concretions (cf. Figure 7(2-5)).

4.1.4. Upper Cretaceous Clasts. The Upper Cretaceous clasts are carbonates from the Teutoburger Wald (Cenomanian to Santonian) and Dammer Berg (Campanian) regions of Germany (Figure 2(a)) that weather easily (except for the Campanian flint nodules, but these are absent from the Cenomanian to Santonian). The platy flints, which show little rounding, (Figure 4(23)) possibly originated from the Dammer Berge region. The Maastrichtian marine carbonate deposits in the studied region are not represented but typical black flint from further west in Belgium is common, including the "Maas-Eggs" (Figure 4(8)) that can sometimes be found in the Dalum gravels. Other red-to-brown flint variants resemble the "Rijckholt" flint (Figures 4(6) and 4(7)), typical of the Campanian limestones in northern Holland and on the Dutch-German border. All of these flint pebbles in the Dalum gravels (except for the platy flints) are well rounded and seem to have been transported to north-west Germany by marine paleocurrents from the west (Figure 5).

4.1.5. Jurassic Clasts. The black silica-ironstone concretions found in these gravels (Figure 4(16)), which resemble black Paleozoic lydite, are from the Middle Jurassic Soninnien beds and are well known in the Osnabrücker Bergland, as well as also being found in reworked Quaternary deposits of the region [23]. Rare, typically red, oolites (iron ores, Figure 4(17)) originate from the Middle Jurassic Macrocephaly oolith beds (also know as "Portha-Oolith or Wittekindsflöz") of the central part of the Wiehengebirge mountain range [24] (Figure 5) and, as with the carbonates, do not survive over long transport distances. In total, the sedimentary clasts from the Jurassic of the Osnabrücker Bergland, and in particular the Wiehengebirge mountain range, are poorly represented and comprise less then $1 \%$ of the total number of clasts (Figure 5).

4.1.6. Lower to Middle Eocene Clasts. The main hard rock types represented from the Lower and Middle Eocene are the phosphorite nodules (Figure 4(20)) that have been reworked from the soft Eocene marine sands (including most of the marine vertebrate remains that accumulated in the Dalum and Osteroden condensed phosphorite nodule gravels), and possibly some white fine-grained sandstones (Ypresian,
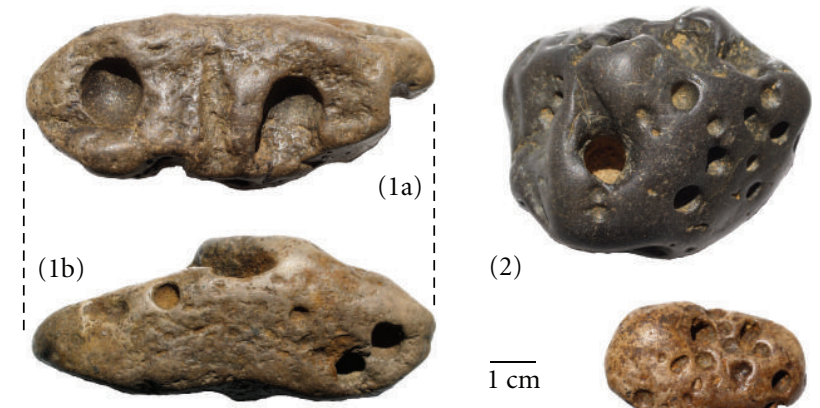

(2)
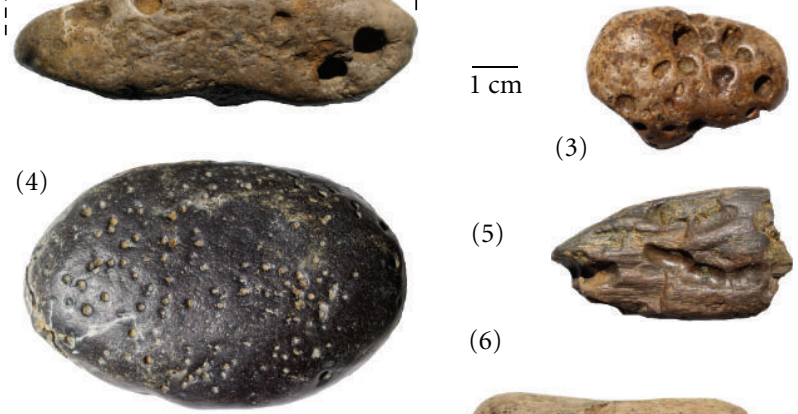

(5)

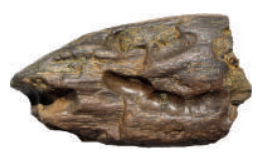

(6)

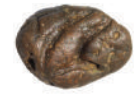

(7)

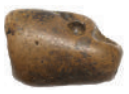

(8)

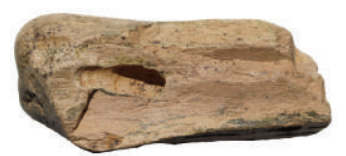

Figure 6: Bored and drilled beach pebbles from the Middle Eocene (Lutetian) gravels at Dalum. Only softer rock types, such as iron-carbonate concretions (Valanginian-Hauterivian, Lower Cretaceous) and phosphorite nodules, or wood (Paleocene-Eocene, Paleogene) were drilled by bivalves or were chemically dissoluted by sponges. (1) Large Gastrochaenolites boreholes in reworked Lower Cretaceous iron-carbonate concretion pebble (SCB no. Dal-Invert2). (2) Small Gastrochaenolithes boreholes in reworked Eocene phosphorite (SCB no. Dal-Invert-1). (3) Small Gastrochaenolithes boreholes in reworked Lower Cretaceous iron-carbonate concretion pebble (SCB no. Dal-Invert-3). (4) Small boreholes made by Clionetype sponges in reworked Eocene phosphorite (SCB no. Dal-Invert4). (5) Boreholes of the bivalve Teredo sp. in Paleogene (Eocene) silicified driftwood (SCB no. Dal-Invert-6). (6) Boreholes of the bivalve Teredo sp. in silicificated Eocene driftwood pieces (SCB no. Dal-Invert-7). (7) Boreholes in reworked Lower Cretaceous ammonite fragment, iron-carbonate concretion (SCB no. DalInvert-5a). (8) Small Gastrochaenolithes boreholes in reworked Lower Cretaceous orthicon ammonite fragment (Bochianites), ironcarbonate concretion (SCB no. Dal-Invert-5b).

Figure 4(13)). The more polished pebbles appear to have come from the older Lower Eocene (Paleocene) horizons that have been reported from other Paleogene sites in northwest Germany [13] and have later been reworked and bored by organisms during the Middle Eocene (Figures 6(2) and 6(4)), while the unpolished phosphorites (Figure 4(20)) may be younger (Middle Eocene) or else have not travelled as far. Also less-transported are sporadic phosphatic shark coprolites, some of which have been reworked from earlier Eocene horizons (Figures 4(21) and 4(22)).

The quantitative rock-type analysis (Figure 5) is based on 3,927 pebbles greater than $4 \mathrm{~mm}$ (Table 2, Figure 5). The main rock types identified were abundant Carboniferous (Westphalian C-D) quartzites and (less common) quartzite conglomerate clasts (59\%), Lower Cretaceous (Valagin/Hauterive) iron-carbonate concretions and fossils 
TABle 2: Fossil types at the Dalum site, based on 14,440 specimens in material $>4 \mathrm{~mm}$.

\begin{tabular}{lc}
\hline Fossil type & Amount \\
\hline Plants & 173 \\
Burrows/boreholes in pebbles & 184 \\
Burrows (refilled, phosphatic) & 43 \\
Bivalves (fragments) & 61 \\
Gastropods & 25 \\
Crustaceans & 29 \\
Anthozoans & 4 \\
Chimaera & 15 \\
Rays & 206 \\
Sharks & 13,690 \\
Turtles & 5 \\
Crocodiles & 3 \\
Mammals & 2 \\
\hline
\end{tabular}

(20\%), and Paleogene (Paleocene) Eocene phosphorite nodules $(15 \%)$. These three main rock types derived from different directions and have been reworked from sediments of different ages (Figure 5). While the Carboniferous material must have been washed in from the south east by a river passing the Schafberg and reaching into a fluvial delta system, the Lower Cretaceous pebbles and fossils were washed opposite south and south east towards the coast, together with the Paleogene phosphorite and fossil material (Figure 5). All other rock types and components are less well represented and not important to the reconstruction of paleocurrents and erosional history.

4.2. Fossil Content. In total, 14,437 fossils were recovered from the Dalum site excavation; these are listed by fossil type in Table 2. Nearly all of the Eocene invertebrate remains are only preserved in the reworked phosphorites; the only fossils preserved by silica replacement are the shells of larger oysters (with silica rings) and the solitary corals. The phosphatic coprolites, the silicified wood, all the bones, and in particular the teeth, were the most resistant specimens.

4.2.1. Invertebrates. The invertebrate fauna is very incomplete and largely represented by phosphorite steinkerns of shells and burrow casts that survived the enrichment processes in the Middle Eocene gravels of Dalum.

Drills and Boreholes. Drills and boreholes in pebbles [25] are quite common in pebble-rich beach Eocene paleoenvironments also found in the Oligocene pebble-rich beaches of north-west Germany [26]. The mechanical bivalve drills and chemical sponge boreholes in the Eocene pebbles from the Dalum site have only been made in soft to moderately hard rock types, and in particular in $85 \%$ of the reworked Lower Cretaceous iron-carbonate nodules (as in the Oligocene beach pebbles from the Osnabrück Bergland region) [26] and ammonite fragments; they are less common in Eocene phosphorites. The two typical ichnites of Gastrochaenolites isp. produced by bivalves (Figures 6(1-3), 6(7) and 6(8)), and
Clione sponge burrows (Figure 6(4)), are common in Lower Cretaceous iron-carbonate concretion pebbles and lesser in Eocene phosphorite pebbles. Teredo bivalve boreholes are also present, but only abundant in driftwood (Figures 6(5) and $6(6))$.

Anthozoans. Corals without reef structures are known throughout the southern North Sea basin, represented by the solitary coral Paracyathus caryophyllus. The few specimens of this coral that have been recovered have been preserved by metasomatic silica replacement (Figure 8(12)). This solitary, nonhermatypic coral is also found in Oligocene shallow marine, beach pebble paleoenvironments $[26,27]$.

Crustaceans. These are common in the Eocene North Sea basin $[28,29]$, but in the Dalum material they are only preserved in the reworked phosphorite concretions. The remains of Hoploparia sp. (Figures $7(6-8)$ ) are significant as these lobsters could be largely responsible for the high degree of bioturbation in the glauconitic sands (Osteroden section, cf. Figures 3(d), 7(1)) and may have been responsible for the Ophiomorpha isp. burrows (Figure 7(1)), fragments of which are also found (as phosphorite concretion casts) within the gravels (Figures $7(2)$ and $7(3)$ ). Smaller burrows, especially the y-shaped forms (Figures 7(4) and 7(5)), may also be related to smaller crustaceans. Crab remains are more common and at least three different species can be identified from their pincers and carapaces: Xanthilithes sp. (Figures 7(11) and 7(12)), Zanthopsis (Figure 7(9)), and Litoricola/Portunites (Figure 7(10)).

Molluscs. Bivalves have been identified following the published works on the Belgian [30, 31] and English [7] sites. In the Dalum material almost all of these have been destroyed because of their aragonite shells, with only a few infaunistic forms such as Arca sp. and Striarca sp. (Figure $8(9)$ ) preserved in phosphorite concretions, some epifaunistic forms such as Pteria sp. (Figure 8(10)), and the more abundant large oyster Pycnodonte sp. (only shell fragments preserved by metasomatic silica replacement), which seem to have settled on the gravels of the pebble beaches. The gastropods are more diverse with at least eight species represented (all reworked Eocene phosphorite steinkerns, Figures $8(1-8)$ ), although most of the specimens are from the infaunistic Natica sp.; epifaunistic forms include Sconsia sp., Cyprea sp., Tectonatica sp., and Xenophora sp.

4.2.2. Vertebrates. The chimera, shark, and ray material was compared to the main important works on PaleoceneEocene sharks of Europe [5, 7, 32-39]. The vertebrates remains are dominated by shark teeth $(95 \%)$, followed by remains of rays $(2 \%)$; the rest are chimera, bony fish, reptile, and (extremely rare) mammal remains (Table 2, Figure 5).

Chimera. Only one chimera species, Edaphodon bucklandi Agassiz, 1843, has been recorded to date; it is represented by jaw fragments (Figure 14(19)). 


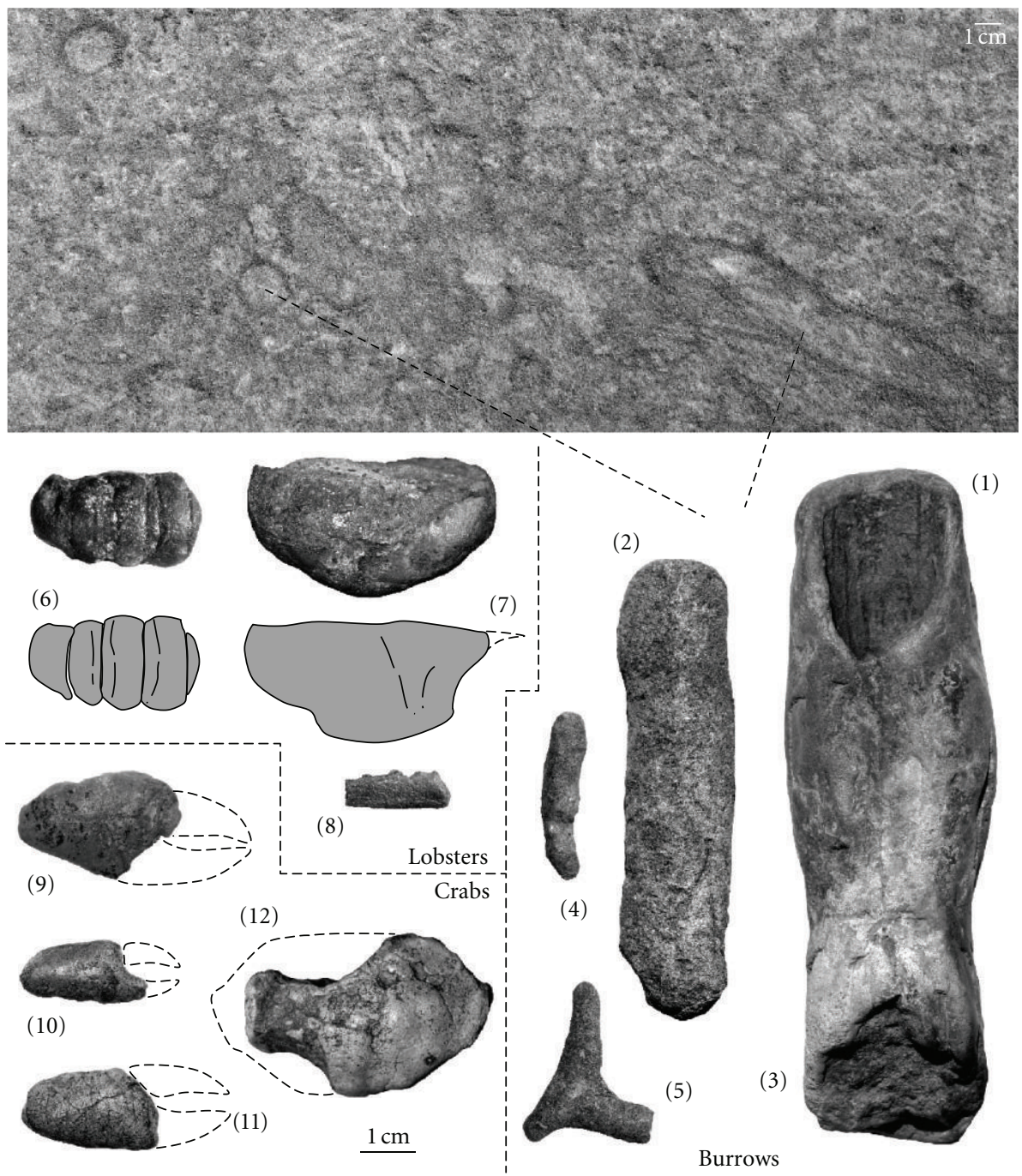

FIGURE 7: Crustacean remains and burrows from the Middle Eocene (Lutetian) gravels at Dalum. (1) Burrows by crustaceans, with large burrows of Ophiomorpha isp. and other smaller burrows in bioturbated glauconitic sands of the Fürstenau Fm. at the Osteroden sand pit (see also burrows in Figure. 3(d)). (2) Refilled Ophiomorpha isp. burrow fragment, phosphorite concretion (SCB no. Invert-41). (3) Encrusted Ophiomorpha isp. burrow fragment, phosphorite concretion (SCB no. Invert-38). (4) Refilled burrow fragment, phosphorite concretion (SCB no. Invert-40). (5) Triaxonic burrow fragment, phosphorite concretion (SCB no. Invert-39). (6) Abdomen fragment from the lobster Hoploparia sp., phosphorite concretion (SCB no. Invert-14), dorsal. (7) Carapace of the lobster Hoploparia sp., phosphorite concretion (SCB no. Invert-16), lateral. (8) Lower pincer of the lobster Hoploparia sp., phosphorite concretion (SCB no. Invert-13), lateral. (9) Crab Zanthopsis large right pincer, phosphorite concretion (SCB no. Invert-18), anterior. (10) Crab Litoricola/Portunites right pincer, phosphorite concretion (SCB no. Invert-17), anterior. (11) Crab Xanthilites sp. large right pincer, phosphorite concretion (SCB no. Invert-20), anterior. (12) Crab Xanthilites sp. carapace in phosphorite concretion (SCB no. Invert-19), dorsal.

Rays. These are the second most common type of fish remains, represented mainly by broken teeth, but also by fin spines. At least four species can be recognised from their teeth including Aetobatus irregularis (Agassiz, 1843), Leidybatis jugosus (Leidy, 1876), Myliobatis dixoni (Agassiz, 1843), and one large unidentified species (Figures 14(1417)), while Pristis lethami Galeotti, 1837, is represented by several rostral tooth fragments (Figure 14(18)).

Sharks. Out of the total of 13,690 Paleogene shark teeth recovered from the Dalum site, 6,946 (more then 50\%) have been identified at a species level (Table 3 ). This large number of identifications is a result of the large quantity of material and many complete and comparable teeth recovered, from different jaw positions in different species. The preliminary qualitative analysis herein includes only 19 of the larger Paleogene shark species and five ray species ( $>4 \mathrm{~mm}$ material), which can be found listed in Table 3 together with their time ranges and abundances. Preliminary sampling of the material below $4 \mathrm{~mm}$ indicates twice as much fish biodiversity, including of course the smaller species whose teeth are, however, quite rare.

Large teeth from Otodus obliquus (Agassiz, 1843; Figure $9(1-3)$ ) are all incomplete and mostly very rounded, 


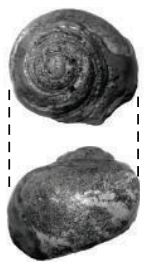

(1)

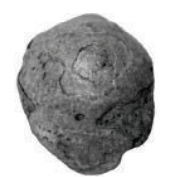

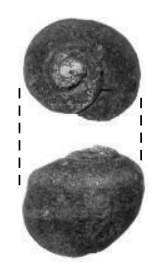

(2)

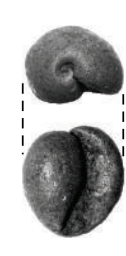

(3)

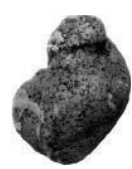

(4)

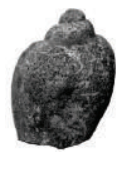

(5)

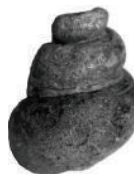

(6)

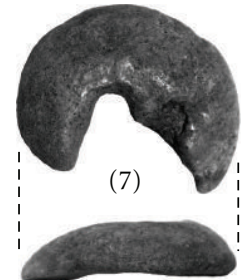

(12)

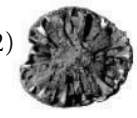

(9)

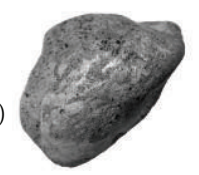

(10)

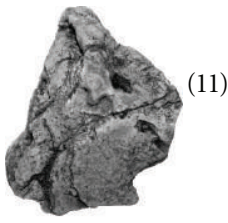

(8)

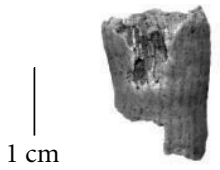

Figure 8: Mollusc and anthozoa remains from the Middle Eocene (Lutetian) gravels at Dalum. (1) Gastropod Natica sp., phosphorite steinkern (SCB no. Invert-25), dorsal and lateral. (2) Gastropod Sconsia sp., phosphorite steinkern (SCB no. Invert-27), dorsal and lateral. (3) Gastropod Cyprea sp. phosphorite steinkern (SCB no. Invert-29), dorsal and lateral. (4) Gastropod Tectonatica sp., phosphorite steinkern (SCB no. Invert-26), lateral. (5) Gastropod Volutospina sp. phosphorite steinkern (SCB no. Invert-30), lateral. (6) Gastropod Littoriniscala sp., phosphorite steinkern (SCB no. Invert-32), lateral. (7) Gastropod Xenophora sp. phosphorite steinkern (SCB no. Invert-28), dorsal and lateral. (8) Gastropod Falsifusus sp. phosphorite steinkern-negative (SCB no. Invert-31), lateral. (9) Bivalve Striarca sp. phosphorite steinkern (SCB no. Invert-34), lateral. (10) Bivalve Pteria sp., phosphorite steinkern (SCB no. Invert-35), lateral. (11) Oyster Pycnodonte sp., shell fragment, metasomatically replaced, silicified (SCB no. Invert-36), lateral. (12) Anthozoa Paracyathus caryophyllus, metasomatically replaced, silicified (SCB no. Invert-37), lateral and dorsal.

but the sharp-edged teeth illustrated herein would appear to be more or less autochthonous (also rare sharp edged in abundant Striatolamia teeth), which is significant because this species now appears to extend from the Paleocene into the lower Middle Eocene in Europe, but not into the middle or upper parts of the Middle Eocene. All of the large teeth from Carcharocles subserratus (Agassiz, 1843; Figure 9(4-10)) are rounded, indicating most probably in all cases the reworking of horizons that appear to extend into the upper Paleocene or Lower Eocene. However, this material may partly belong to the most abundant type of white shark, Carcharodon auriculatus (Blainville, 1818), which is represented by both enrolled teeth and sharp serrated teeth, from various jaw positions (Figures 10(1-8)). The largest and most robust teeth recovered from the Dalum site are from the megatooth shark lineage-Carcharocles sokolovi (Jaeckel, 1895) - which is not well defined, and is rare in any material. All of the megatooth shark ancestor material will be discussed further in the future, when more teeth are available (only 13 have been recovered to date, and only two of these are in good condition: Figures $10(9)$ and 10(10)) and can be better distinguished from the other serrated teeth. Another, more abundant, species is Isurus praecursor (Lériche, 1905), with material from all jaw positions (Figure 11(1-10)). Jaeckelotodus is represented by two species, J. trigonalis (Jaeckel, 1895) from which all teeth are reworked (Figures 11(11-15)), and J. robustus (Lériche, 1921) which has both reworked and sharp-edged specimens (Figures 11(16-18)). The most abundant shark is the sand shark ancestor Striatolamia macrota (Agassiz, 1843), with teeth present from all the main jaw positions (Figure 12) and including teeth from juveniles right through to teeth from mature individuals. Only $0.1 \%$ of the teeth are sharp edged with little evidence of any transport. Smaller species are also abundant, such as Sylvestrilamia teretidens (White, 1931; Figures 13(1-12)), and Hypotodus verticalis (Agassiz, 1843; Figures 13(13-19)). Less abundant are teeth from Anomotodon novus (Winkler, 1874; Figures 13(20-22)) which are all reworked, as is also largely the case with teeth from Brachycarcharias lerichei (Casier, 1946; Figures 14(16)). This latter species sometimes also has sharp-edged teeth, such as Carcharias sp. (Figures 14(7) and 14(8)). Rare teeth from some other species are also present (Table 3, Figures 14(9) and 14(13)).

Bone Fish. Some vertebrae and teeth, mainly from Phylodus sp. (Figure 14(20)) and Pycnodus sp. (Figure 14(21)) and some rostrum fragments from Cylindracanthus sp. (Figure 14(22)) provide only a poor representation of the diverse fish fauna, which is normally estimated from the otoliths, but these are absent from Dalum.

Terrestrial Vertebrates. Only single vertebrate teeth have been described from Early to Middle Eocene marine deposits around the world $[4,7,40]$, but large pachyostotic rib fragments from Dalum appear to be attributable to early marine Sirenian mammals when compared to Oligocene material [41], and these rare Middle Eocene marine mammal remains will be described in a future publication. The terrestrial vertebrate remains recovered from the Dalum material are of rare crocodile teeth, osteoderm fragments from Diplocynodon (Figures 15(1) and 15(2)), and freshwater turtle remains of Trionyx (Figure 15(3)), all of which are suggestive of freshwater lakes or swamps and therefore a possible deltaic environment.

Some bone fragments are impossible to identify but appear to relate to mammals, judging by their spongious nature. A distal humerus fragment (Figure 15(4)) appears to 


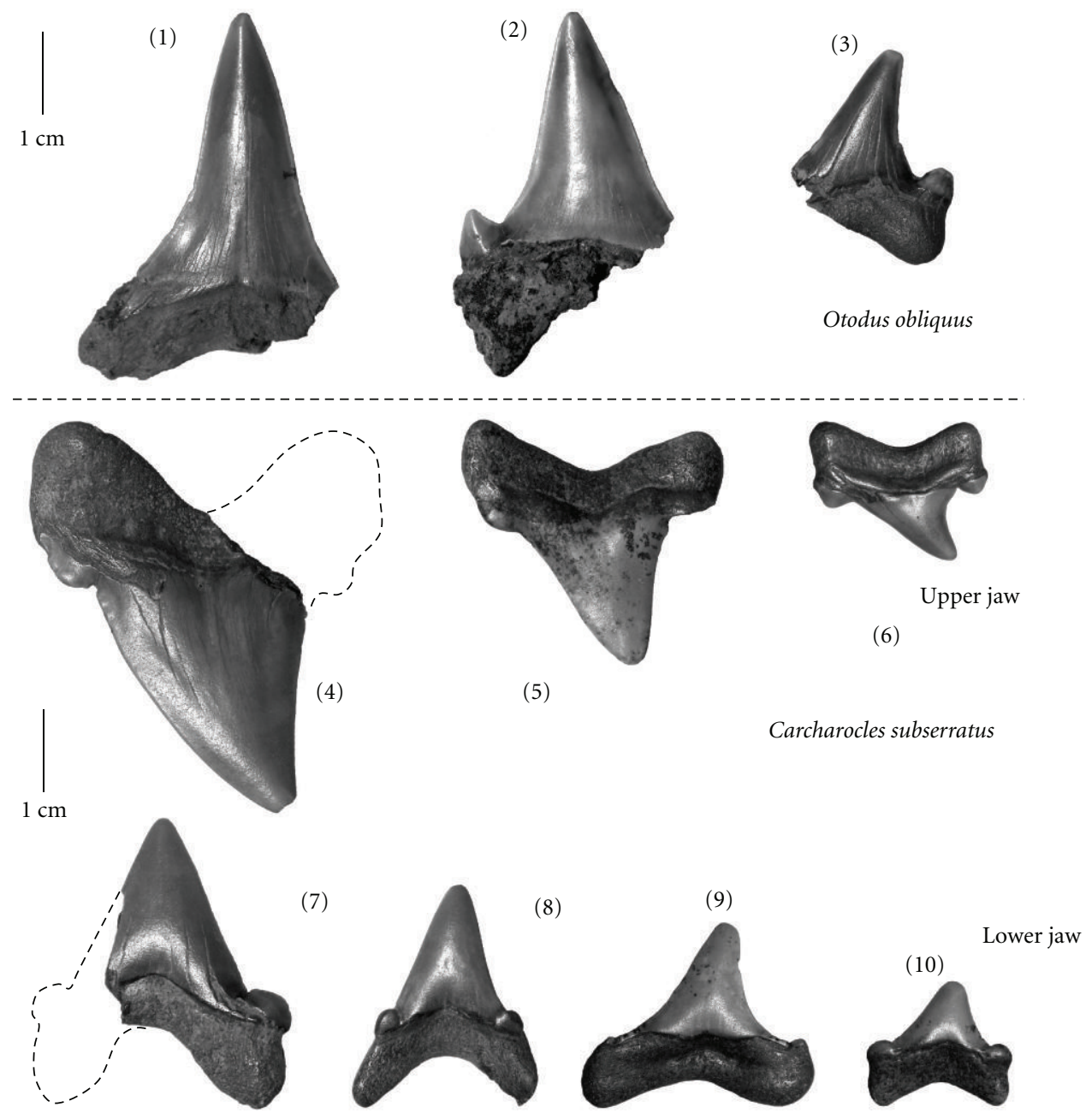

FIGURE 9: Shark teeth from lamniform (Odontidae) sharks (from different jaw positions) from the Middle Eocene (Lutetian) gravels at Dalum. (1-3). Otodus obliquus (Agassiz, 1843): (1) lower jaw anterior tooth (SCB no. Sel-856), (2) lower jaw anterolateral tooth (SCB no. Sel-857), and (3) lateral tooth (SCB no. Sel-858). (4-10). Carcharocles subserratus (Agassiz, 1843): (4) upper jaw anterior tooth (SCB no. Sel-869), (5) upper jaw lateral tooth (SCB no. Sel-870), (6) upper jaw posterolateral tooth (SCB no. Sel-872), (7) lower jaw anterior tooth (SCB no. Sel-873), and (8) Lower jaw anterolateral tooth (SCB no. Sel-874), (9) lower jaw lateral tooth (SCB no. Sel-876), (10) lower jaw posteriolateral tooth (SCB no. Sel-875; all in labial view).

belong to a medium-sized marine mammal, and a femur fragment (Figure 15(5)) may belong to a larger mammal.

\section{Discussion}

5.1. Stratigraphy and Dating. The sediments from the 22meter-thick sections at Dalum and Osteroden have a different lithology from the Lower to Middle Eocene Brussel and Lede Sand Formations of the Belgian Oosterzele and Balegem marine deposits [42]. They also contain less carbonate and no storm shell beds, but only massive clay and conglomerate layers, and hence a new formation name is proposed for these deposits: the Fürstenau Formation.

At the Dalum site only the older (Ypresian) Eocene layers are present, with initial marine sequences possibly overlain by a massive clay bed, although precise dating of this part of the section is not yet available. The conglomerate layer can be dated by the terrestrial mammal teeth (MP 11 zone), as at Balegem, in Belgium [4, 43], and by shark teeth indicating the presence or absence of certain species (e.g., $O$. obliquus). The more carbonate-influenced Middle Eocene conglomerates (two horizons) of the Lede Sand Formation at Balegem and Osterzele [44] have been described as being of Middle Lutetian age, and may therefore possibly be slightly younger than those from northern Germany $[1,5]$. The condensed phosphorite gravel beds at Dalum and Osteroden may be isochronous with the two bivalve-enriched condensed beds in the middle Middle Eocene Lede Sand Formation of Belgium $[42,45]$. The conglomerates at Dalum and Osteroden also appear to be isochronous with the Lower Geiseltalium, and would therefore be of a similar age to the Messel and older Geiseltal mammal faunas [9].

The marine clay-sand parasequences of the Fürstenau Formation have been dated by nannoplankton into the 

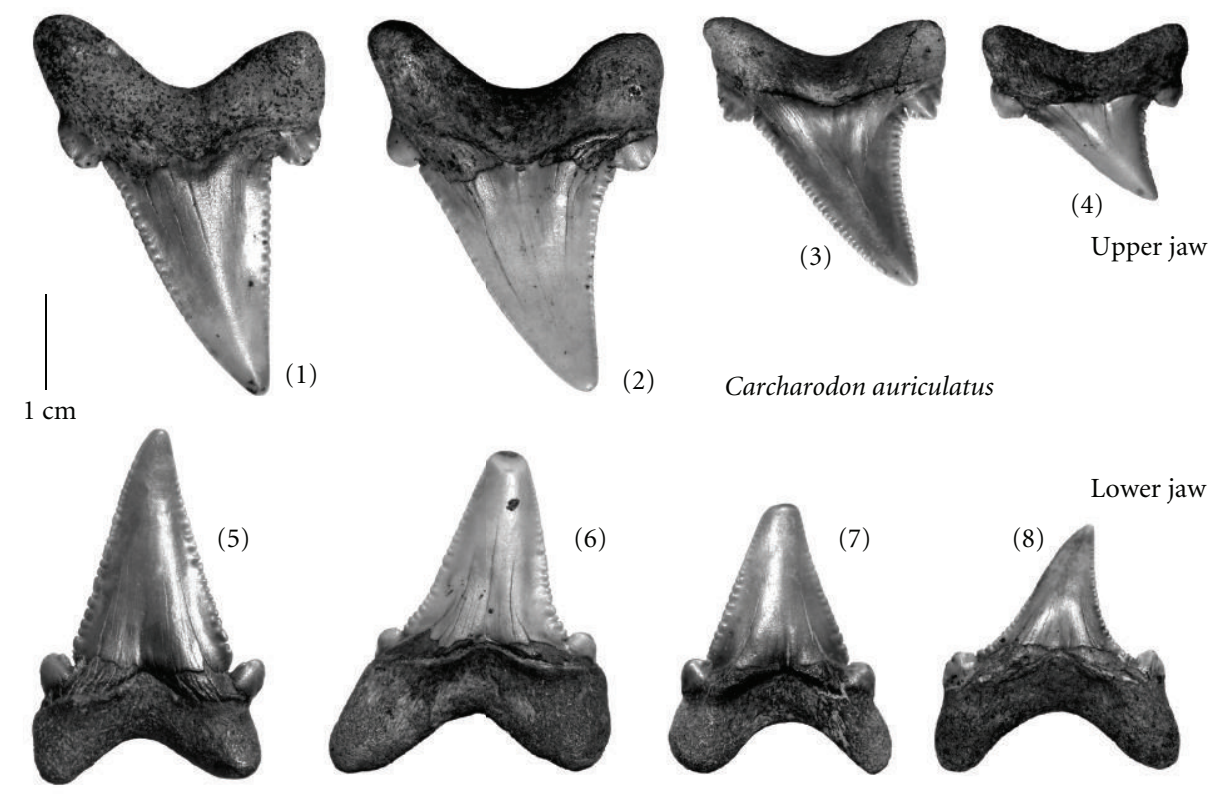

(2)

Carcharodon auriculatus
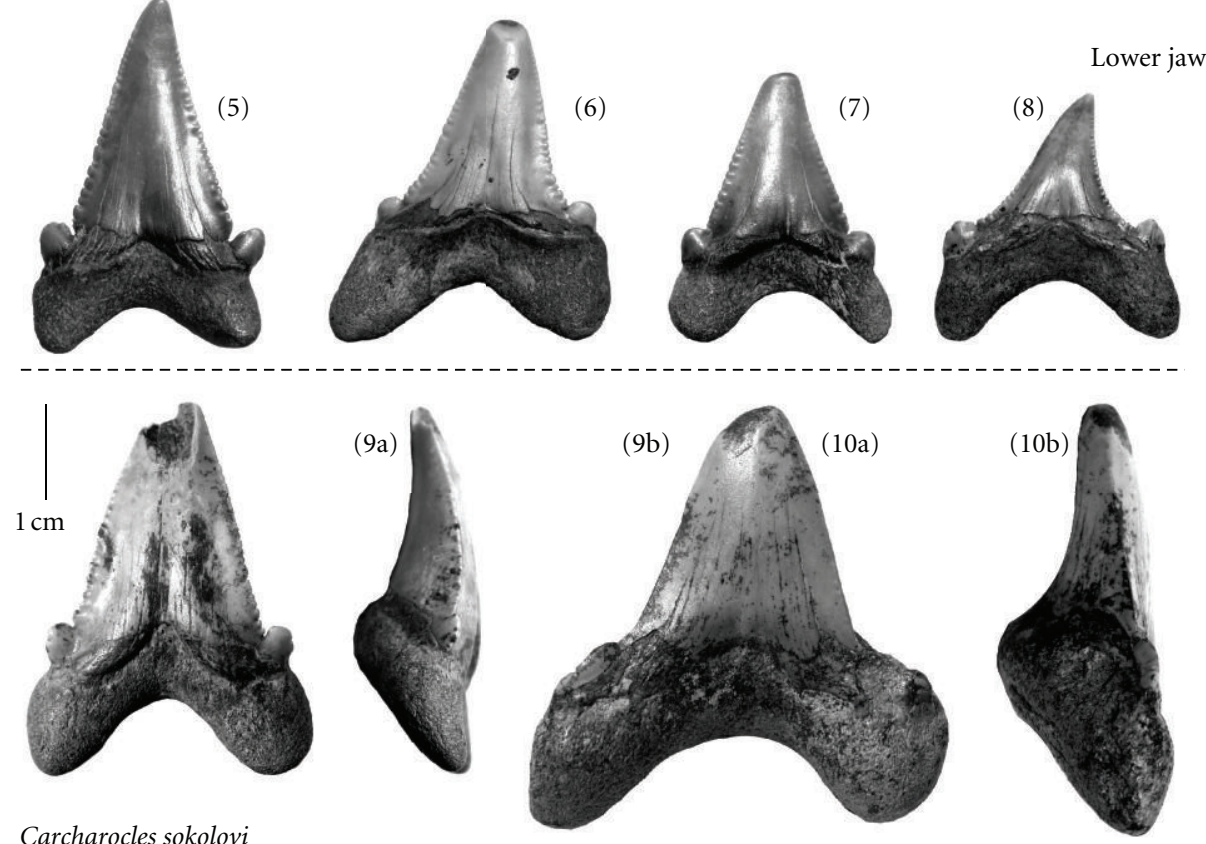

FIgURE 10: Shark teeth from lamniform (Carcharidae) sharks (from different jaw positions) from the Middle Eocene (Lutetian) gravels at Dalum. (1-8) Carcharodon auriculatus (Blainville, 1818): (1) upper jaw anterior tooth (SCB no. Sel-26), mirrored, (2) upper jaw anterolateral tooth (SCB no. Sel-25), (3) upper jaw anterior lateral tooth (SCB no. Sel-27), mirrored, (4) upper jaw posterior lateral tooth (SCB no. Sel65), mirrored, (5) lower jaw anterior tooth (SCB no. Sel-4), mirrored, (6) lower jaw anterolateral tooth (SCB no. Sel-5), mirrored, (7) lower jaw anterior lateral tooth (SCB no. Sel-7), (8) lower jaw posterior lateral tooth (SCB no. Sel-66; (1-2(a)) labial and (b) lateral, (3-10), labial views). (9-10) Carcharocles sokolovi (Jaeckel, 1895): (1) lower anterior tooth (SCB no. Sel-85) and (2) lower anteriolateral tooth (SCB no. Sel-88).

middle Middle Eocene (Lutetian, NP 14 zone [46, 47]) and appear to be nonisochronous with the shark-toothrich layers at Balegem (NP 15 zone) [43, 48]. The lithology of the newly introduced Fürstenau Formation differs from that of the marine localities in the southern North Sea and Paris Basins in having a much lower carbonate content, an almost complete absence of sandstone beds, and an absence of the bivalve (dominated by the bivalve Megacardita) and gastropod shell beds.

At least two shark species appear to be from reworked Upper Cretaceous deposits, represented by some teeth from Cretolamna appendiculata and a single tooth from Squalicorax kaupi (Figures 4(24) and 4(26)). Upper Paleocene and Lower Eocene tooth material appears to be particularly well represented by Carcharocles obliquus and Otodus subserratus. While O. obliquus is typically present in the Late Paleocene and Lower Eocene of Europe (cf. London Clay in: [7]) it is represented here by sharp-edged teeth that show little signs of transport, and so its time range may extend into the Early Lutetian. In contrast, O. obliquus and C. appendiculata, are both absent from the diverse selachian fauna of Middle Lutetian age in Belgium [5]. The Carcharodon auriculatus teeth from Dalum and Osteroden in Germany, and those from Balegem and Oosterzele in Belgium, differ in their serrations, especially on the lateral cusps which are more strongly developed in the younger material from Belgium [5]. The shark fauna from the Dalum and Osteroden gravels appears to be a little younger than the Middle Eocene Belgian faunas, which supports the dating of the Dalum and Osteroden gravels (but not all the teeth therein) into the Early Lutetian transgression (Early Middle Eocene [48], during which older Paleogene tooth material was reworked and concentrated.

5.2. Biodiversity and Facies. The mollusc population seems to be represented by forms from the sandy floor of a shallow 


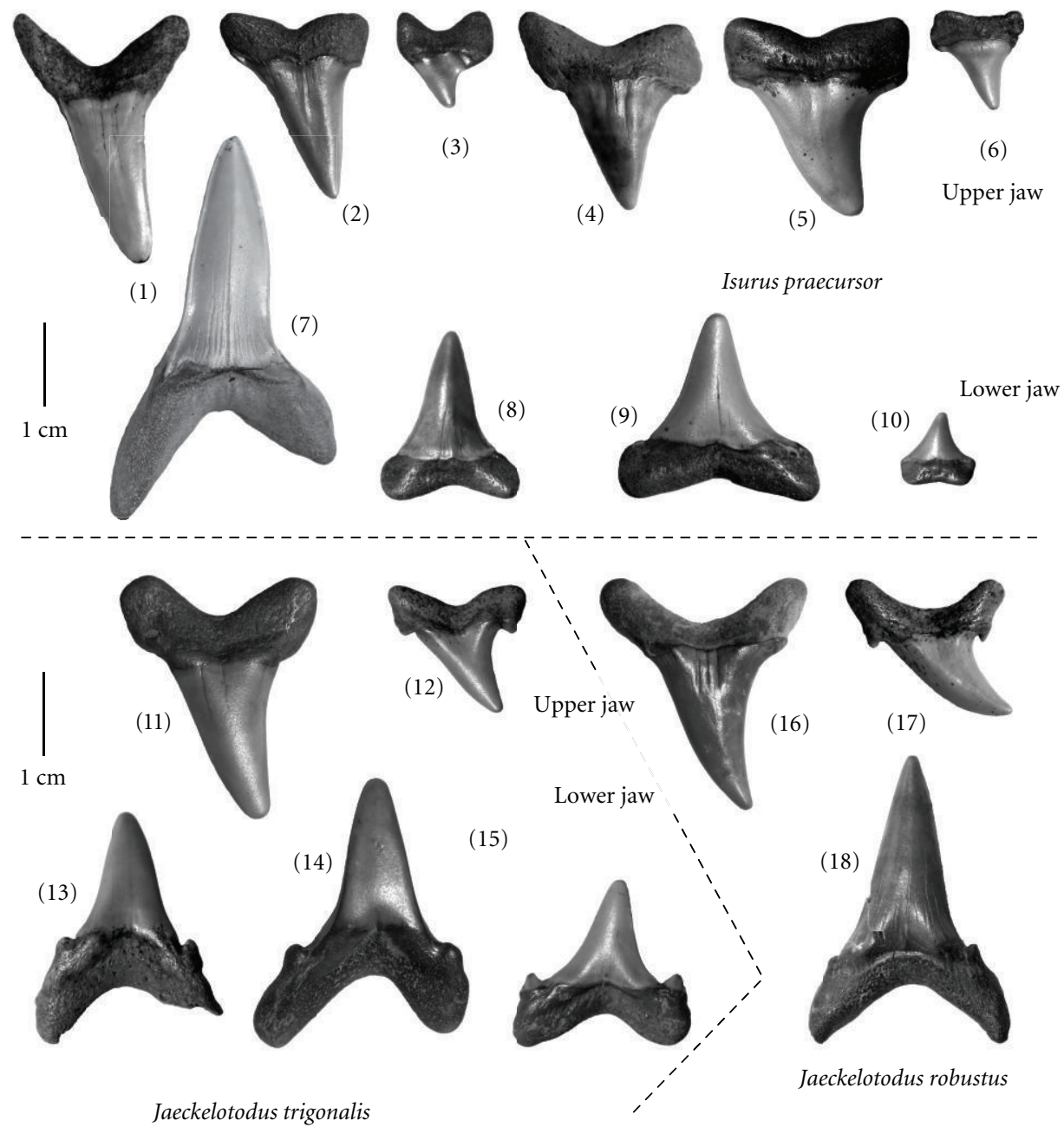

Figure 11: Shark teeth from lamniform (Lamnidae, Jaeckelotodontidae) sharks (from different jaw positions) from the Middle Eocene (Lutetian) gravels at Dalum. (1-10) Isurus praecursor (Lériche, 1905): (1) first upper anterior tooth (SCB no. Sel-101), 2. upper jaw anterior tooth (SCB no. Sel-117), (3) second upper jaw tooth (SCB no. Sel-112),(4) upper jaw anterolateral tooth (SCB no. Sel-124), (5) upper jaw anterior lateral tooth (SCB no. Sel-123), (6) upper jaw posterior lateral tooth (SCB no. Sel-125), (7) first lower jaw anterior tooth (SCB no. Sel-97), (8) second lower jaw anterolateral tooth (SCB no. Sel-109), (9) lower jaw middle lateral tooth (SCB no. Sel-104), (10) lower jaw distal lateral tooth (SCB no. Sel-108). (11-15) Jaeckelotodus trigonalis (Jaeckel, 1895): (11) upper jaw anterior tooth (SCB no. Sel-157), (12) upper jaw lateral tooth (SCB no. Sel-156), (13) lower jaw first anterior tooth (SCB no. Sel-160), (14) lower jaw anterolateral tooth (SCB no. Sel-158), (15) lower jaw lateral tooth (SCB no. Sel-159). (16-18) Jaeckelotodus robustus (Lériche, 1921): (16) upper jaw anterolateral tooth (SCB no. Sel-131), (17) upper jaw lateral tooth (SCB no. Sel-137), and (18) lower jaw anterior tooth (SCB no. Sel-129; all in labial view).

sea, although only rudimentary taphonomic comparisons have been made to the Belgian and English sites [7, 30, 31]. There is anyway too little material available at this stage for a model to be made of the autochthonous benthic fauna on the sandy sea floor. The invertebrate fauna of the Middle Eocene beach gravel paleoenvironment is expected to be restricted, with a dominance of oysters [26], as has been demonstrated for the Oligocene pebble beaches of northwest Germany. Oysters such as Pycnodonte appear to have been attached to the gravels, but proof is yet to be found in the fragmented material from Dalum. The solitary corals are also in same state of preservation as the oysters and would not have survived any significant amount of transport, which means that they are also likely to have been attached to the gravels. A restriction of the marine invertebrate benthic fauna must also be expected due to the freshwater influence, but further analysis of the Osteroden site, with its wellpreserved mollusc assemblages (Felker pers. com.) is still required.

The vertebrates are dominated by the ancestral sand shark Striatolamia macrota (Figure 12, Table 3), which appears to have also had nursery schools in those shallow waters, as indicated by the presence of teeth from all sizes of animals including many very small teeth from young individuals. Most interesting in the shark research are two different "white and megatooth shark" ancestors, one with massive and the other with slim tooth morphologies: the megatooth shark ancestor Carcharocles sokolovi (the massive-toothed form) [49], and the great white shark ancestor Carcharodon auriculatus (the smaller form) [49]. 
(7)

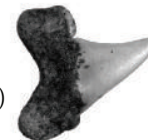

(6)

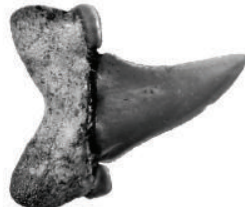

(5)

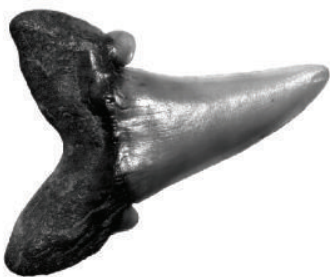

(4)

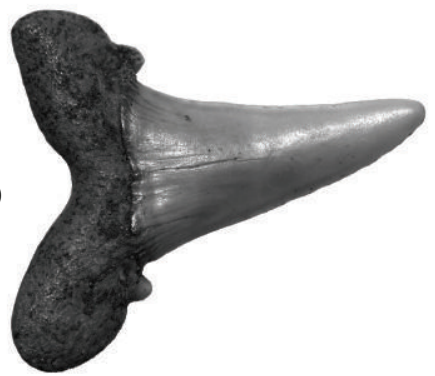

(3)

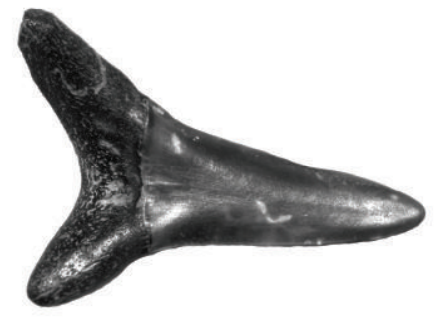

(2)

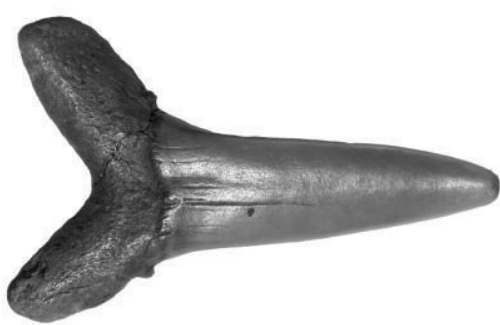

(1)

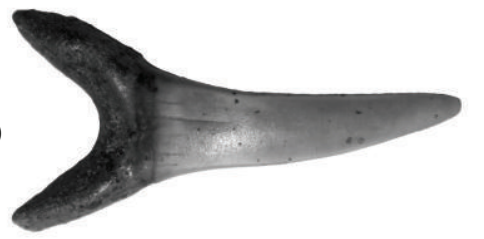

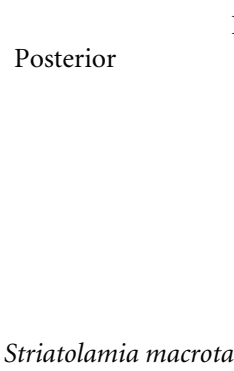

Lower jaw

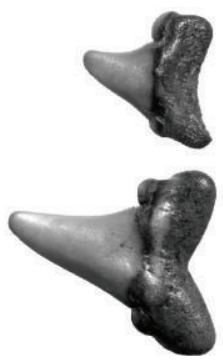

(15)

(14)

Striatolamia macrota

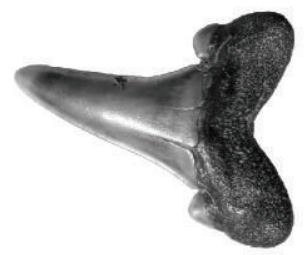

(13)

(12)

(11)

(10)

(9)

Anterior

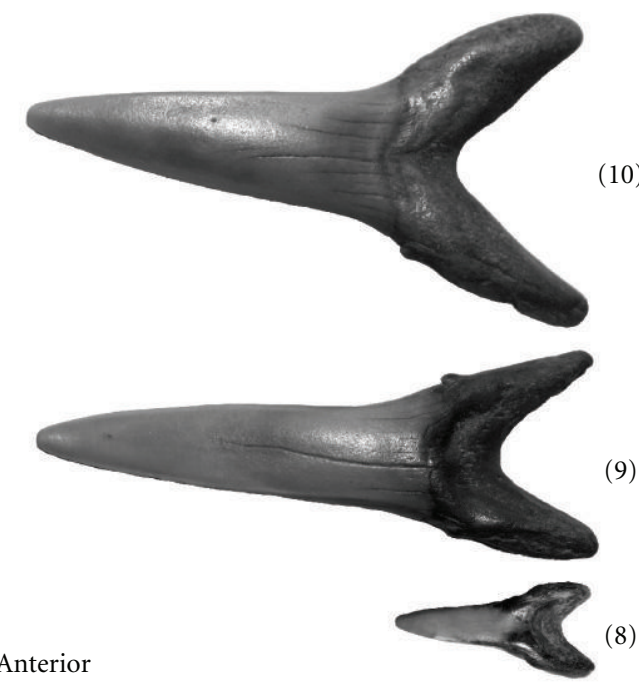

Figure 12: Shark teeth from lamnid (Odontaspididae) Striatolamia macrota (Agassiz, 1843) sharks (from different jaw positions) from the Middle Eocene (Lutetian) gravels at Dalum. (1) upper jaw first tooth (SCB no. Sel-195), (2) upper jaw second tooth (SCB no. Sel-179), (3) upper jaw third tooth (SCB no. Sel-212), (4) upper jaw fifth tooth (SCB no. Sel-195), (5) upper jaw middle lateral tooth (SCB no. Sel-172), (6) upper jaw middle lateral tooth (SCB no. Sel-171), (7) upper jaw posteriolateral tooth (SCB no. Sel-220), (8) lower jaw first (symphyseal) tooth (SCB no. Sel-167), (9) lower jaw second tooth (SCB no. Sel-168), (10) lower jaw third tooth (SCB no. Sel-169), (11) lower jaw fourth tooth (SCB no. Sel-170), (12) lower jaw anterior lateral tooth (SCB no. Sel-217), (13) lower jaw middle lateral tooth (SCB no. Sel-218), (14) lower jaw distal lateral tooth (SCB no. Sel-219), and (15) lower jaw posterolateral tooth (SCB no. Sel-214; and all in labial view). 
TABLE 3: Shark species from the Dalum site based on the number of identifiable teeth $>4 \mathrm{~mm}$.

\begin{tabular}{lcc}
\hline Sharks & Quantity & Time range \\
\hline Striatolamia macrota & 5,901 & Paleocene-Eocene \\
Carcharodon auriculatus & 455 & Middle/Upper Eocene \\
Isurus praecursor & 179 & Lower/Middle Eocene \\
Sylvestrilamia teretidens & 95 & Eocene \\
Hypotodus verticalis & 64 & Eocene \\
Carcharocles subserratus & 48 & Lower Eocene \\
Otodus obliquus & 47 & Paleocene-Lower Eocene \\
Jaeckelotodus robustus & 46 & Lower/Middle Eocene \\
Brachycarcharias lerichei & 36 & Eocene \\
Jaeckelotodus trigonalis & 33 & Lower/Middle Eocene \\
Carcharocles sokolovi & 13 & Middle Eocene-Lower Oligocene \\
Carcharias sp. & 12 & Eocene \\
Anomotodon novus & 5 & Eocene \\
Isurolamia affinis & 4 & Eocene \\
Galeocerdo latidens & 3 & Eocene \\
Pachygaleus lefevrei & 2 & Eocene \\
Xiphodolamia ensis & 1 & Eocene \\
Usakias wardi & 1 & Eocene \\
Odontaspis winkleri & 1 & Eocene \\
Total & 6,946 & \\
Selachii Indet. & 6,737 & \\
Total number of teeth & 13,683 & \\
\hline
\end{tabular}

Two different "large serrated shark" forms can therefore be shown (from the well-dated and large quantities of teeth) to have already developed by the basal Middle Eocene, both of which will need to be further analysed in greater detail on the basis of the material from Dalum in order to further define the ancestry of the white/megatooth sharks and their evolutionary record, which remains as yet unclear, controversial, and a matter of some discussion $[49,50]$. The Dalum material includes intermediate forms between Otodus obliquus and Carcharocles sokolovi, such as Carcharocles subserratus whose teeth seem to have all been reworked from Lower Eocene horizons, as have most of the O. obliquus teeth. The origin of the white/megatooth shark lineage will be investigated using about 1,000 serrated shark teeth from the two sites at Dalum and Osteroden, which is possibly the largest collection in general [51], and for the Eocene period in particular.

5.3. Paleogeographic Reconstruction and Paleoenvironment. Analysis of conglomerate pebbles and the reworked Mesozoic fossils has allowed a detailed paleogeographic map of the Osnabrück region, north of the Rhenish Massif, to be prepared, revising the former less refined models $[13,16,20]$. Previous pebble analysis work by Bartholomäus [2], in which the iron-carbonate clasts, ammonite fragments, and several pebble types were not recognised, has been considerably extended herein.

Large quantities of Paleozoic quartzite material (from Carboniferous sandstones and conglomerates) must have been transported, mainly from Schafberg area but also from the Piesberg area (see Carboniferous horst structures and Westphal C-D sandstones [21]), which appears to have been the result of major erosion under a tropical climate by an ancient (hypothetically reconstructed) river that flowed during the Middle Eocene between the mountain chains that today form the Wiehengebirge and Teutoburger Wald ranges (Figure 5). This river also may also have transported Paleozoic gravels (including lydite) from the Rhenish Massif. Only the hard silica-rich rock types could have survived longdistance transport. With such a river and a tropical climate an estuarine or deltaic situation can be expected at its mouth [52], as has been reconstructed herein (on a preliminary basis) using only the two Dalum and Osteroden sections and their differences in gravel thickness. Dalum would have been more proximal $(80 \mathrm{~cm}$ thickness $)$ than Osteroden $(40 \mathrm{~cm}$ thickness) in the deltaic fan (see [52]). More sections and drill cores from the Fürstenau area will need to be studied in the future in order to obtain an improved understanding of this paleoenvironment. The conglomerates can anyway not be simply treated as tempestites or as being of purely transgressive origin $[1,13]$, as they are demonstrated herein to be a combination of marine transgressive and fluvial deltaic deposits. The Lower Cretaceous (Valanginian/Hauterivian) iron-carbonate concretions, the smaller burrows, and the many ammonite fragments, with all softer rock types showing burrows and boreholes from Eocene times (Figure 5), were transported during the Early Eocene (Ypresian [19]) and subsequently reworked during the Middle Eocene from the Early Eocene marine deposits, or possibly even reworked twice, and finally accumulated north of the Wiehengebirge mountain range (to the north-west of Osnabrück) in the southern pre-North Sea basin coastal pebble facies that were mixed with deltaic deposits (Figure 5).

The region north-west of Fürstenau (i.e., the Dalum/ Osteroden region) represents a deltaic, fresh-water-influenced, low-carbonate, siliciclastic glauconite sand to pebble facies in the shallow marine coastal environment of the southern pre-North Sea basin, to the north of the Rhenish Massif. In contrast, the Belgian (Balegem/Osterzele) region was more carbonate influenced and was located in shallow marine areas between the southwestern pre-North Sea and the Paris Basins [44]. The Osterzele and Balegem facies had similarities with the Middle Eocene facies from north-west Germany, but had less terrestrial influences whereas in the Lower Eocene London Clay Formation the terrestrial input was even higher into the coastal paleoen- vironments [14].

\section{Conclusion}

The Middle Eocene (Lutetian) transgressive conglomerates from Dalum and Osteroden in north-west Germany are a mixture that includes reworked Lower Cretaceous (Valanginian-Hauterivian) marine claystones, with the derived ammonite fragments and pebbles making up 20\% of the total number of clasts. About $80 \%$ of these reworked Lower Cretaceous pebbles contain burrows or boreholes (e.g., Gastrochaenolithes boreholes made by bivalves). Boreholes have also been left in driftwood by the bivalve Teredo. 

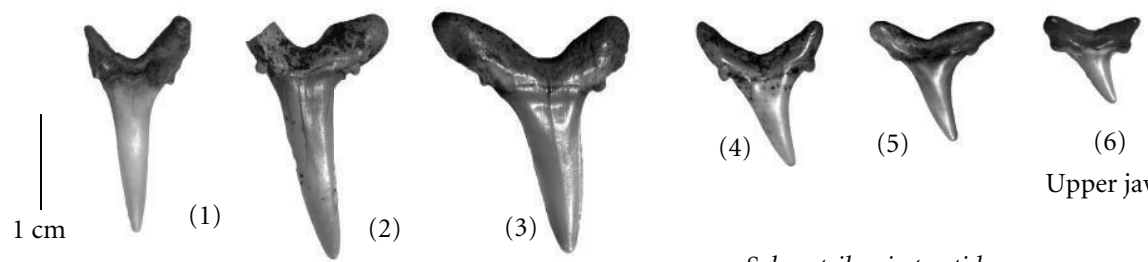

Upper jaw

Sylverstrilamia teretidens
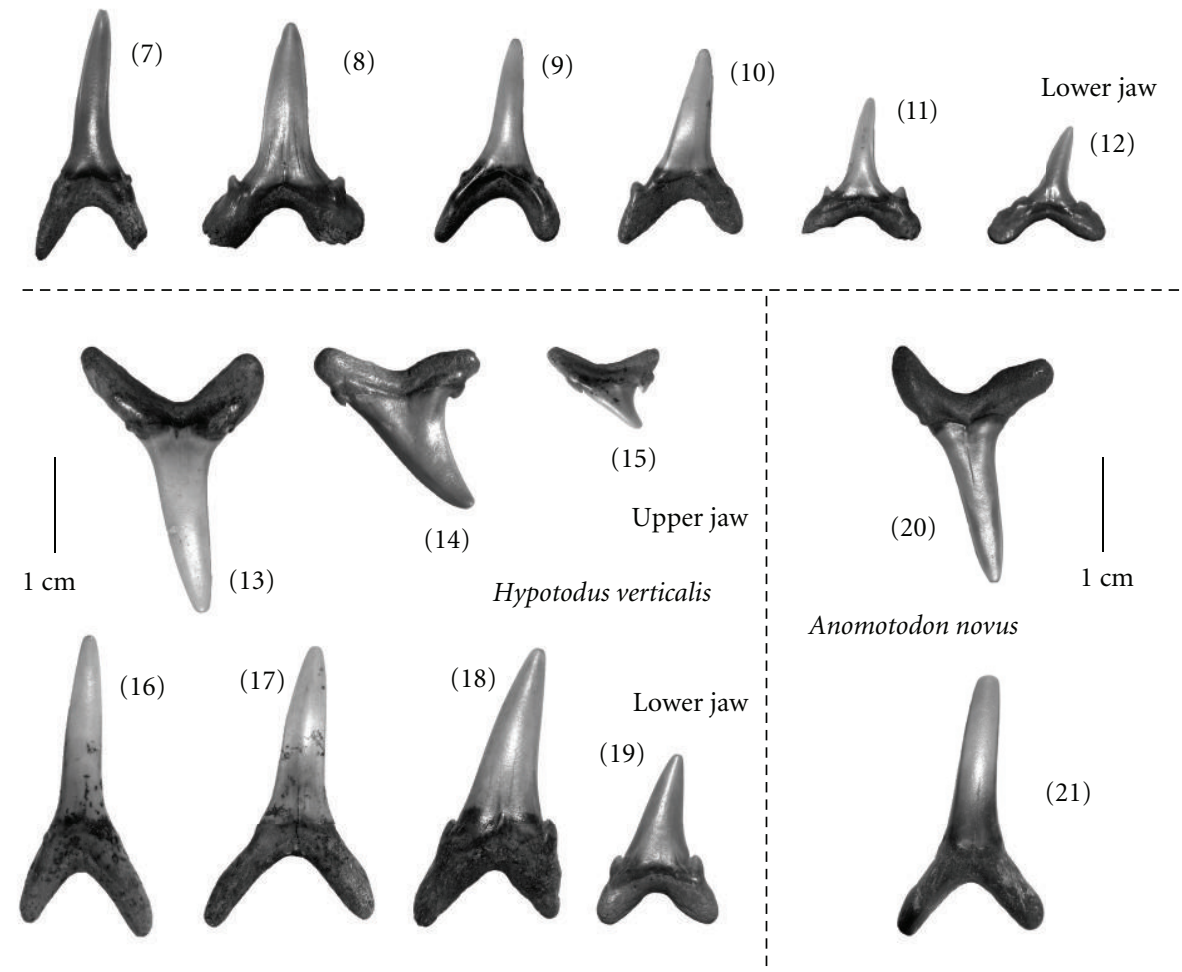

Figure 13: Shark teeth from lamniform (Odontaspididae, Mitsukurinidae) sharks (from different jaw positions) from the Middle Eocene (Lutetian) gravels at Dalum. (1-12). Sylvestrilamia teretidens (White, 1931): (1) upper jaw first anterior tooth (SCB no. Sel-832), (2) upper jaw second anterior tooth (SCB no. Sel-833), (3) upper jaw third anterior tooth (SCB no. Sel-834), (4) upper jaw middle lateral tooth (SCB no. Sel-835), mirrored, (5) upper jaw middle lateral tooth (SCB no. Sel-836), mirrored, (6) upper jaw posteriolateral tooth (SCB no. Sel837), (7) lower jaw second anterior tooth (SCB no. Sel-838), (8) lower jaw third anterior tooth (SCB no. Sel-839), (9) lower jaw anterior tooth (SCB no. Sel-840), (10) lower jaw anterolateral tooth (SCB no. Sel-841), (11) lower jaw middle lateral tooth (SCB no. Sel-843), and (12) lower jaw posterior lateral tooth (SCB no. Sel-845), mirrored. (13-19). Hypotodus verticalis (Agassiz, 1843): (13) upper jaw anterior tooth (SCB no. Sel-823), (14) upper jaw middle lateral tooth (SCB no. Sel-824), (15) upper jaw posteriolateral tooth (SCB no. Sel-825), (16) lower jaw second anterior tooth (SCB no. Sel-827), (17) lower jaw third anterior tooth (SCB no. Sel-828), (18) lower jaw fourth anterior tooth (SCB no. Sel-829), (19) lower jaw middle lateral tooth (SCB no. Sel-826). (20-22) Anomotodon novus (Winkler, 1874): (20) upper jaw anterior tooth (SCB no. Sel-818), and (21) Lower jaw anterior tooth (SCB no. Sel-819), (22) lower jaw anterior tooth (SCB no. Sel-; 820) all in labial view).

In addition, Paleogene phosphorite nodules sometimes contain benthic marine invertebrate fauna (and also burrow casts). These were transported southward to the pebble beach coast, as were all the Lower to basal Middle Eocene vertebrate remains and, in particular, the shark teeth that are highly concentrated within these gravels, with a density of about 5,000 per cubic meter of gravel.

The other main components of the conglomerate are Paleozoic (Carboniferous) siliciclastic sandstones, and the (mostly well-rounded) quartzites that make up 59\% of the pebbles, but these must have been transported by river and come from the opposite direction, deriving from the mainland to the south. An ancient river between the
Wiehengebirge and Teutoburger Wald mountain ranges must have flowed to the west of Osnabrück and the Carboniferous Schafberg where a river passed to the west of the main quartz source. Even the resistant sandstone rocks were affected by weathering in the harsh tropical climate. A "Fürstenau-Delta" is postulated, with a conglomerate thickness of about $80 \mathrm{~cm}$ in Dalum (proximal) and $40 \mathrm{~cm}$ in Osteroden (distal), suggesting a deltaic fan close to the western end of the mountain chains on the Rhenish Massif mainland. The coastline during the Early Eocene (Ypresian) was a little further south, and later moved some tens of kilometres north of the Wiehengebirge mountain range, where it was during the Middle Eocene (Lutetian). 


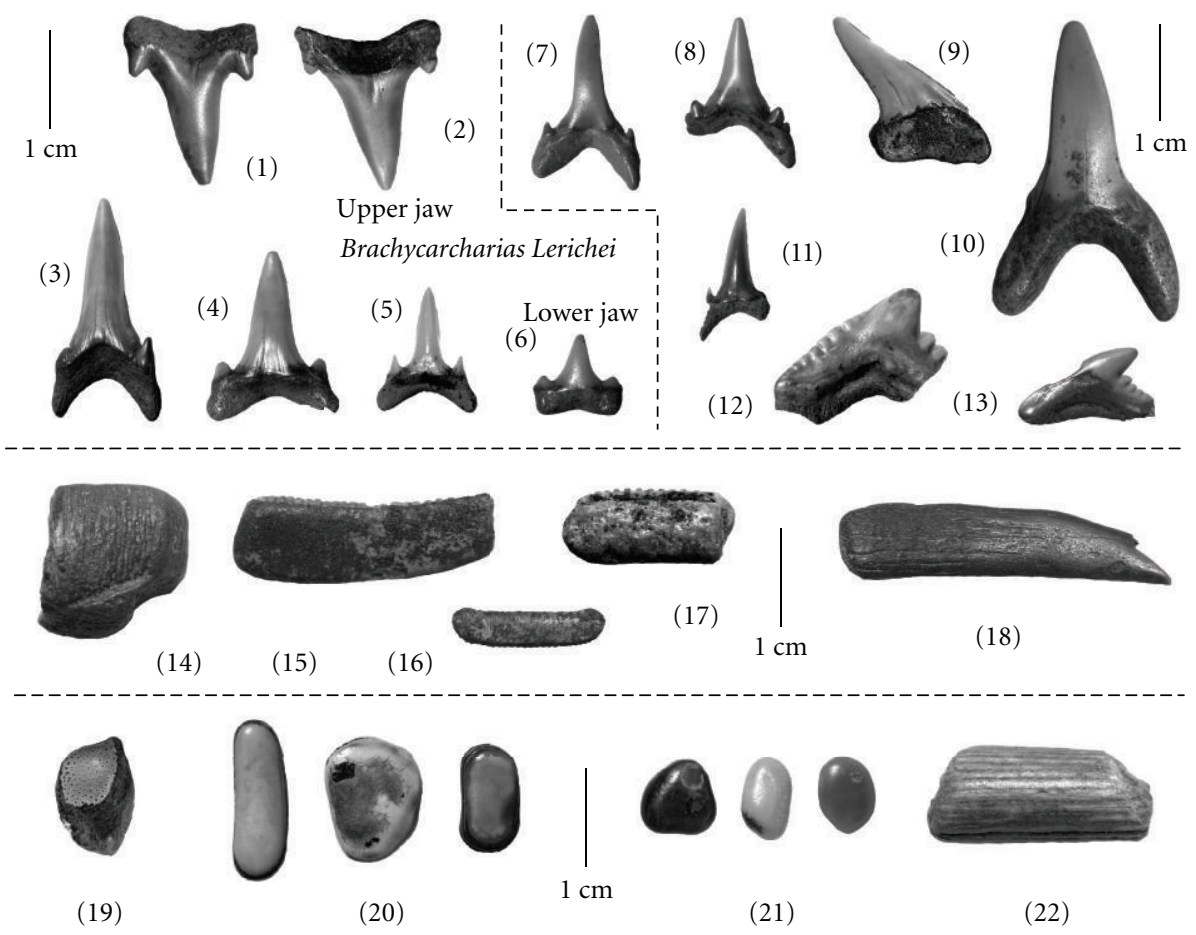

FIGURE 14: Shark teeth from rare shark species, rays, chimaera, and bony fish remaining from the Middle Eocene (Lutetian) gravels at Dalum. 1-6. Brachycarcharias lerichei (Casier, 1946): (1) upper jaw second anterior tooth (SCB no. Sel-849), (2) upper jaw third anterior tooth (SCB no. Sel-850), (3) lower jaw first anterior tooth (SCB no. Sel-851), (4) lower jaw third anterior tooth (SCB no. Sel-848), (5) lower jaw lateral tooth (SCB no. Sel-852), (6) lower jaw posterolateral tooth (SCB no. Sel-853). 7-8. Carcharias sp.: (7) lower jaw anterolateral tooth (SCB no. Sel-878), (8) lower jaw lateral tooth (SCB no. Sel-879). (9) Xiphodolamia ensis Leidy, 1877 upper jaw second tooth (SCB no. Sel-859). (10) Isurolamna affinis (Casier, 1946) lower jaw first anterior tooth (SCB no. Sel-865). (11) Otodus winkleri Lériche, 1905 upper jaw anterolateral tooth (SCB no. Sel-883). (12) Galeocerdo eaglesomei (White, 1955) tooth (SCB no. Sel-2). (13) Pachygaleus lefevrei (Dammeries, 1891) tooth (SCB no. Sel-1). (14) Tooth from a large unidentified ray (SCB no. Bat-7). (15) Aetobatis irregularis (Agassiz, 1843) tooth fragment (SCB no. Bat-4). (16) Leidybatis jugosus (Leidy, 1876) tooth (SCB no. Sel-902). (17) Myliobatis dixoni (Agassiz, 1843) tooth fragment (SCB no. Bat-6). (18) Pristis lathami Galeotti, 1837 rostral tooth (SCB no. Bat-9). (19) Edaphodon bucklandi Agassiz, 1843 (SCB no. Chim-1). (20) Phylodus sp. teeth (SCB no. Tel-1). (21) Pycnodus sp. three lateral row teeth (SCB no. Tel-2). (22) Cylindracanthus sp. rostrum fragment (SCB no. Tel-8). (1-13 labial view).

The northern Rhenish Massif (the Westphalian Cretaceous Basin/Bay) was not flooded during a medium high stand of the Early to Middle Eocene pre-North Sea Basin, nor was the area between the Wiehengebirge and Teutoburger Wald mountain ranges subjected to marine flooding. The area between the Wiehengebirgs and Teutoburger Wald mountain ranges was, however, subjected to flooding later during the Oligocene (Latdorfian to Chattian), when the old river drainage system of Eocene times was flooded and destroyed.

The shark fauna is mainly dominated by the sand shark Striatolamia macrota, for which a full range of ages is well represented. Otodus obliquus is also another common large shark. A "great white" shark ancestor is represented by teeth from Carcharodon auriculatus and a megatooth shark ancestor by the larger and more massively rooted teeth of Carcharocles sokolovi. Other moderately common sharks include Isurus praecursor, Jaeckelotodus robustus, and J. trigonalis. The Otodus obliquus, and C. subserratus teeth, in particular, appear to indicate reworking of older Early Eocene marine sediments, which are known to exist in northwest Germany. All of the other large shark species (teeth
$>4 \mathrm{~mm}$ ), out of a total of 19 that have been identified, are more rare. The larger sharks show a moderate degree of biodiversity and do not indicate tropical marine water temperatures, nor does the absence of coral reefs and the low carbonate production, which is in contrast to the terrestrial tropical forest mammal fauna biodiversity of the Rhenish Massif Mainland.

\section{Acknowledgments}

The excavation field project was sponsored by the "Geoand Naturpark TERRA.Vita" (H. Escher), and the Landkreis, Osnabrück. The private company "PaleoLogic" was responsible for the field work and sponsoring of the scientific research. Special thanks are due to A. Felde from the Reuter company for his excellent work with the backhoe, and to the company for its full support. The Kuhlhoff Education Center leaders Mr. A. Bruns and Mr. W. Hollermann, and the mayor of Bippen, Mr. H. Tolsdorf, are thanked for their managements to install the field sieving laboratory and for any support. Finally, the author would also like to 


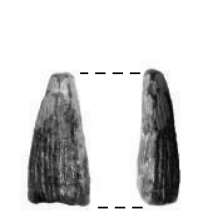

(1)

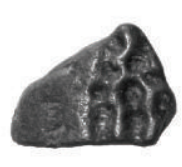

(2)

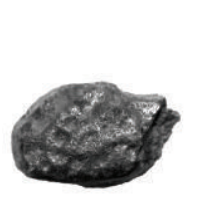

(3)
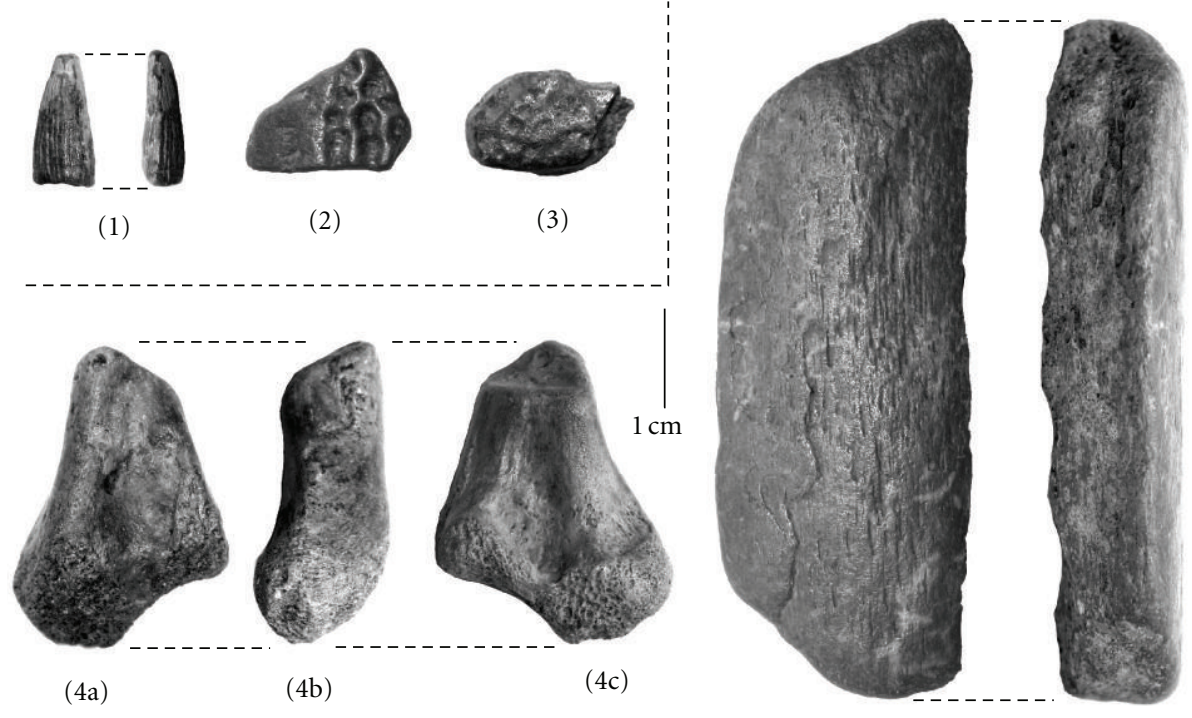

(5)

FIGURE 15: Reptile and mammal remains form the Middle Eocene (Lutetian) gravels at Dalum. (1) Crocodile tooth from Diplocynodon (SCB no. Rept-1), labial and lateral. (2) Crocodile osteoderm fragment from Diplocynodon (SCB no. Rept-2), dorsal. (3) Turtle Trionyx osteoderm fragment (SCB no. Rept-3), dorsal. (4) Distal joint of a humerus from an unidentified medium-sized mammal (SCB no. Mam-1), (a) dorsal, (b) lateral, and (c) ventral. (5) Femur fragment from an unidentified large mammal (SCB no. Mam-2), dorsal and lateral.

thank H. Felker, a local hobby paleontologist, who provided support, helped with sieving the material, and allowed access to his large collection (obtained over 25 years from both localities (Dalum and Osteroden) for comparisons.

\section{References}

[1] F. Hocht, "Eine Lagerstätte kreidezeitlicher und paläogener Chondrichthys-Reste bei Fürstenau (Niedersachsen)," Osnabrücker Naturwissenschaftliche Mitteilungen, vol. 6, pp. 35-44, 1979.

[2] W. A. Bartholomäus, "Ein kondensiertes Knochenlager im marinen Alttertiär von Fürstenau/SW-Niedersachsen," Fossilien, vol. 2, no. 93, pp. 79-82, 1993.

[3] W. Schwarzhans, "The otoliths from the Middle Eocene of Osteroden near Bramsche, north-western Germany," Neues Jahrbuch fur Geologie und Palaontologie, vol. 244, no. 3, pp. 299-369, 2007.

[4] J. L. Franzen and T. Mörs, "Das nördlichste Vorkommen paläogener Säugetiere in Europa," Palaontologische Zeitschrift, vol. 81, no. 4, pp. 447-456, 2007.

[5] G. Van den Eeckhaut and P. De Schutter, "The Elasmobranch fauna of the Lede Sand Formation at Osterzele (Lutetian, Middle Eocene of Belgium)," Palaeofocus, vol. 1, pp. 1-57, 2009.

[6] M. Lériche, "L’Eocene des Bassins Parisiennes et Belge, Livretguide de la réunion extraordinaire de la Société Géologique de France," Bulletin de la Société Géologique de France, vol. 4, no. 12, pp. 692-807, 1912.

[7] D. Rayner, T. Mitchel, M. Rayner, and F. Clouter, London Clay Fossils of Kent and Essex. Medway Fossil and Mineral Society, Caxton and Holmesdale Press Ltd, Kent, Ohio, USA, 2009.

[8] J.L. Franzen, "The biostratigraphic and palaeoecologic significance of the Middle Eocene locality Geiseltal near Halle (German, Democratic Republic)," Münchner Geowissenchaftliche Abhandlungen A, vol. 10, pp. 93-100, 1987.
[9] S. Schaal and W. Ziegler, Eds., Messel-ein Schaufenster in die Geschichte der Erde und des Lebens, Waldemar Kramer, Frankfurt, Germany, 1988.

[10] F. W. Negendank, G. Irion, and J. Linden, "Ein eozänes Maar bei Eckfeld nordöstlich Manderscheid (SW-Eifel)," Mainzer Geowissenschaftliche Mitteilungen, vol. 11, pp. 157-172, 1982.

[11] H. H. Schleich, "Neue Reptilfunde aus dem Tertiär Deutschlands. 13. Schildkröten- und Krokodilreste aus der eozänen Braunkohle des Untertargebaues Stolzenbach bei Borken (Hessen)," Courier des Forschungsinstitutes Senckenberg, vol. 173, pp. 79-101, 1994.

[12] J.-L. Hartenberger, "Les Mammifères d'Egerkingen et l'histoire des faunes de l'Eocène d'Europe," Bulletin de la Société Geologique France, Serie VII, vol. 12, no. 5, pp. 886-893, 1970.

[13] H. Hiltermann, “Tertiär,” in Geologie des Osnabrücker Berglandes, H. Klassen, Ed., pp. 463-494, Osnabrück Germany, 1984.

[14] C. King, "The stratigraphy of the London Clay Formation and Virginia Formation in the coastal sections of the Isle of Sheppy (Kent, England)," Tertiary Research, vol. 5, no. 3, pp. 121-160, 1984.

[15] P. Mangelsdorf, Geologische Wanderkarte Landkreis Osnabrück, Landkreis Osnabrück, Hanover, Germany, 1984.

[16] F. Bettenstaedt, "Paläogeographie des nordwestdeutschen Tertiärs," Erdöl und Tektonik in NW Deutschland, vol. 1941, pp. 143-172, 1949.

[17] F. Bettenstaedt, "Tertiär Norddeutschlands," Leitfossilien der Mikropaläontologie, vol. 1962, pp. 339-379, 1962.

[18] J. Rohling, "Beiträge zur Stratigraphie und Tektonik des Tertiärs in Südoldenburg," Decheniana A, vol. 100, pp. 1-103, 1941.

[19] K. Staesche and H. Hilterman, "Mikrofaunen aus dem Tertiär NW Deutschlands," Abhandlungen der Reichsanstalt für Bodenforschung Neue Folge, vol. 201, pp. 1-26, 1940.

[20] P. A. Ziegler, Geological Atlas of Western and Central Europe, Shell, Amsterdam, The Netherlands, 1990. 
[21] K.-H. Josten, K. Köwing, A. Rabitz et al., "Oberkarbon," in Geologie des Osnabrücker Berglandes, H. Klassen, Ed., pp. 777, Osnabrück, Germany, 1984.

[22] E. Kempe, Die Tiefe Unterkreide im Vechte-Dinkel-Gebiet, Dobler-Druck, Alfeld,Germany, 1992.

[23] C. Diedrich, "Kieselgeoden als wichtiger Rohstoff für die Beilproduktion im Neolithikum von Nordwestdeutschland-erste Nachweise von Produktionsplätzen der Trichterbecherkultur," pp. 1-36, 2004, www.jungsteinsite.de/.

[24] W. Weitschat, "Lias und Dogger," in Geologie des Osnabrücker Berglandes, H. Klassen, Ed., pp. 335-385, Osnabrück, Germany, 1984.

[25] M. Bertling and K. Hermanns, "Autochthone Muschelbohrungen im Neogen des Rheinischen Braunkohlenreviers und ihre sedimentologische Bedeutung," Zentralblatt für Geologie und Paläontologie I, vol. 1995, no. 1-2, pp. 33-44, 1996.

[26] C. Diedrich, "Palaeoecology, facies and stratigraphy of the shallow marine macrofauna from the Upper Oligocene (Palaeogene) in the southern Pre- North-Sea Basin of Astrup near Osnabrück (NW Germany)," Cainozoic Research. In press.

[27] M. Berndt and J. Welle, "Ahermatype Korallen aus dem Oberoligozän der Schächte Rheinberg und Sophia Jacoba 8 (Niederrheinische Bucht)," Neues Jahrbuch für Geologie und Paläontologie Abhandlungen, vol. 198, no. 1-2, pp. 47-68, 1995.

[28] W. J. Quayle, "English Eocene Crustacea (Lobsters and Stomatopods)," Tertiary Research, vol. 30, no. 5, pp. 581-612, 1987.

[29] J. S. H. Collins and J. Saward, "Three new genera and species of crabs from the Lower Eocene London Clay of Essex, England," Bulletin of the Mitzunami Fossil Museum, vol. 33, no. 2006, pp. 67-76, 2002.

[30] M. Gilbert, "Les Bivalvia du Lédien (Eocène ,oyen supérieur) de la Belgique I, Paleotaxodonta, cryptodonta, Pteriomorpha," Bulletin d l'Institut royal des Sciences Naturelles de Belgique/Mededelingen van het Koninklijk Belgish Instituut voor Natuurwetenschappen, vol. 51, no. 3, p. 1, 1975.

[31] M. Gilbert, "Les Bivalvia du Lédien (Eocène ,oyen supérieur) de la Belgique II. Heterodonta, et Anomalodesmata," Bulletin d l'Institut Royal des Sciences Naturelles de Belgique/Mededelingen van het Koninklijk Belgish Instituut voor Natuurwetenschappen, vol. 52, no. 5, pp. 1-80, 1980.

[32] O. Jaeckel, Die Eozänen Selachier aus Monte Bolca, 1894.

[33] O. Jaeckel, "Unter-Tertiäre Selachier aus Südrussland," Mémoires du Comité Géologique de St.-Pétersbourg, vol. 9, pp. 19-35, 1895.

[34] M. Lériche, "Contribution à lètude des poisons fossils du Nord de la France et des regions voisines," Mémoires de la Société Geologique du Nord, vol. 5, pp. 1-430, 1906.

[35] E. Casier, "Contributions à l'étude des poisons fossiles de la Belgique VII-les Pristidés Eocènes," Bulletin de l'Institut Royal des Sciences Naturelles de Belgique/Mededelingen van het Koninklijk Belgisch Instituut voor Naturwetenshappen, vol. 25, no. 19, pp. 1-52, 1949.

[36] E. Casier, "Fauna ichthyologique du London Clay," British Museum Natural History London, vol. 1966, pp. 1-496, 1966.

[37] H. Cappetta, Chondrichthyes II. Mesozoic and Cenozoic Elasmobranchii. Handbook of Paleoichthyology, Gustav Fischer, Stuttgart, Germany, 1987.

[38] H. Cappetta and D. Nolf, "Révision de quelques Odontaspididae (Neoselachii: Lamniformes) du Paléocene et de l'Eocène du Bassin de la mer du Nord," Bulletin de l'Institut Royal des Sciences Naturelles de Belgique/Mededelingen van het
Koninklijk Belgisch Instituut voor Naturwetenshappen, Sciences de la Terre/Aardwetenshappen, vol. 75, pp. 237-266, 2005.

[39] S. Adnet, "Nouvelles faunes de Sélachiens (Elasmobranchii, neoselachii) de l'Eocène moyen des Landes (Sud-Ouest France)," Implications Dans la Connaissance des Communautés de Sélachians Dèaux Profonds. Palaeo Ichthyologica, vol. 10, pp. 1-128, 2006.

[40] S. G. Lucas, "Fossil mammals and the Paleocene/Eocene series boundary in Europe, North Amrica, and Asia," in Late Paleocene-Early Eocene Climatic and Biotic Evolution, M.-P. Aubry, S. Lucas, and W. A. Berggren, Eds., pp. 451-500, Columbia University Press, New York, NY, USA, 1998.

[41] C. Diedrich, "The food of the miosiren anomotherium langenwieschei (Siegfried)_indirect proof of seaweed or seagrass by xenomorphic oyster fixation structures in the Upper Oligocene (Neogene) of the Doberg, Bünde (NW Germany) and comparisons to modern Dugong dugon (Müller) feeding strategies," Senckenbergiana Maritima, vol. 38, no. 1, pp. 5973, 2008.

[42] J. Hermann, E. Steurbaut, and N. Vandenberghe, "The boundary between the Middle Eocene Brussel Sand and the Lede Sand Formations on the Zaventem-Nederokkerzeel area (Northeast of Brussels, Belgium)," Geologica Belgica, vol. 3, no. 3-4, pp. 213-255, 2000.

[43] T. Smith, B. De Wilde, and E. Steurbaut, "Primitive equoid and Tapiroid mammals: keys for interpreting the Ypresian/Lutatian transition in Belgium," Bulletin van het Koninklijk Belgisch Institut voor Natuurwetenshappen, Aardwetenschappen, Supplement, vol. 74, pp. 165-175, 2004.

[44] B. Fobe and V. Spiers, "Sedimentology and facies distribution of the Lede Formation (Eocene) in Belgium and northern France," Contributions to Tertiary and Quaternary Geology, vol. 29, no. 1-2, pp. 9-20, 1992.

[45] P. Jacobs and E. Sevens, "Middle Eocene sequence stratigraphy in the Balegem quarry (Western Belgium, Southern Bigth North Sea)," Bulletin de la Société belge de Géologie/Bulletin van de Belgische Vereniging voor Geologie, vol. 102, no. 1-2, pp. 203-213, 1994.

[46] M.-P. Aubry, "Palaeocene/Eocene boundary events in space and time," Israel Bulletin of Earth Sciences, vol. 44, pp. 1-253, 1998.

[47] H.-P. Lauterbacher, J. R. Ali, H. Brinkhuis et al., "The paleogene period," in A Geological Time Scale, G. M. Gradstein, J. G. Ogg, A. Smith et al., Eds., pp. 384-408, Cambridge University Press, Cambridge, UK, 2004.

[48] W. A. Berggren and M.-P Aubry, "Late Paleocene-Early Eocene NW European and North sea magnetostratigraphic correlation network. A sequence stratigraphic approach," in Correlation of the Early Palaeogene in Northwestern Europe, O. R. B. Knox, R. C. Corfiled, and R. E. Dunay, Eds., vol. 101, pp. 309-352, 1996.

[49] A. Martin, "Systematics of the Lamnidae and the Origination Time of Carcharodon carcharias inferred from the comparative analysis of mitochondrial DNA sequences," in Great White Sharks: The Biology of Carcharodon Carcharias, A. P. Kimley and D. G. Ainley, Eds., pp. 67-78, Academic Press, San Diego, Calif, USA, 1996.

[50] S. P. Applegate and L. Espinosa-Arrubarrena, "The fossil history of Carcharodon and its possible ancestor, Cretolamna: a study in tooth identification," in Great White Sharks-The Biology of Carcharodon Carcharias. Ainley, A. P. Klimley and G. David, Eds., pp. 19-36, Academic Press, San Diego, Calif, USA, 1996. 
[51] D. J. Long and B. M. Waggoner, "Evolutionary relationships of White Shark: a phylogeny of lamniform sharks based on dental morphology," in Great White Sharks-The Biology of Carcharodon Carcharias, A. P. Klimley and G. David, Eds., pp. 37-47, Academic Press, San Diego, Calif, USA, 1996.

[52] H. Füchtbauer and G. Müller, Sedimente und Sedimentgesteine, Schweizbart' sche Verlagsbuchhandlung, Stuttgart, Germany, 1970. 

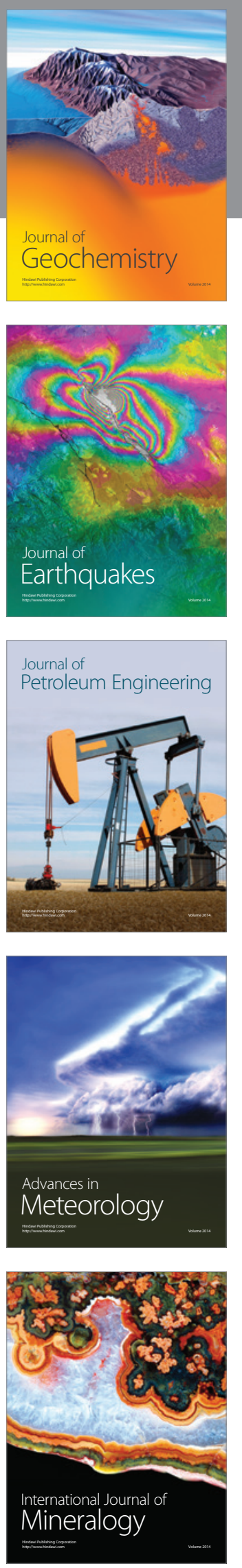
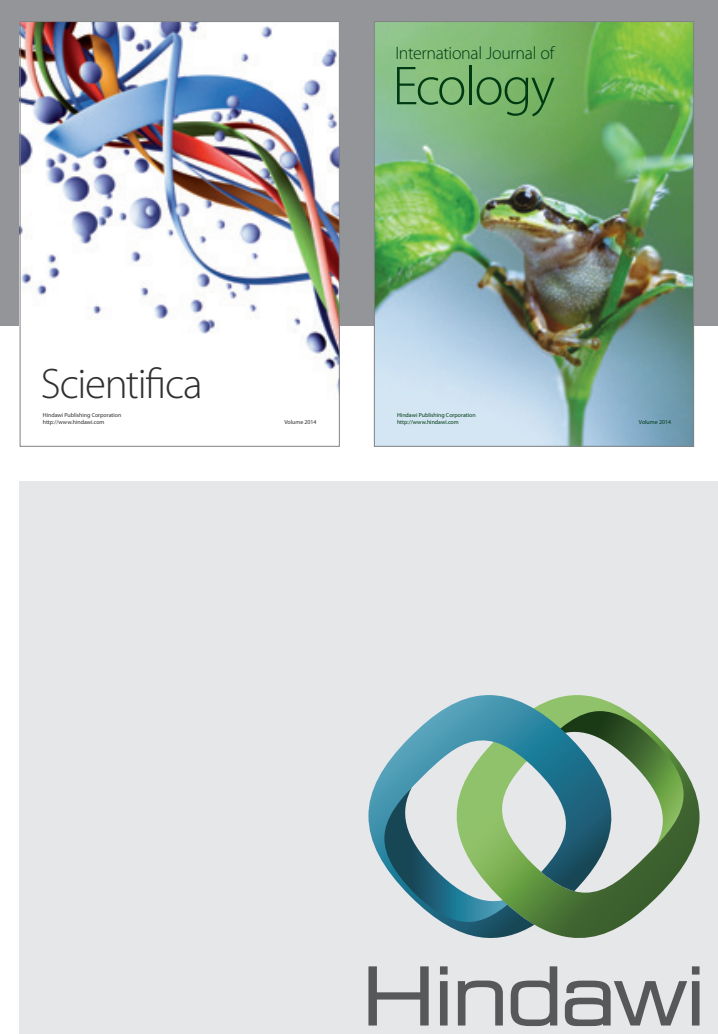

Submit your manuscripts at http://www.hindawi.com
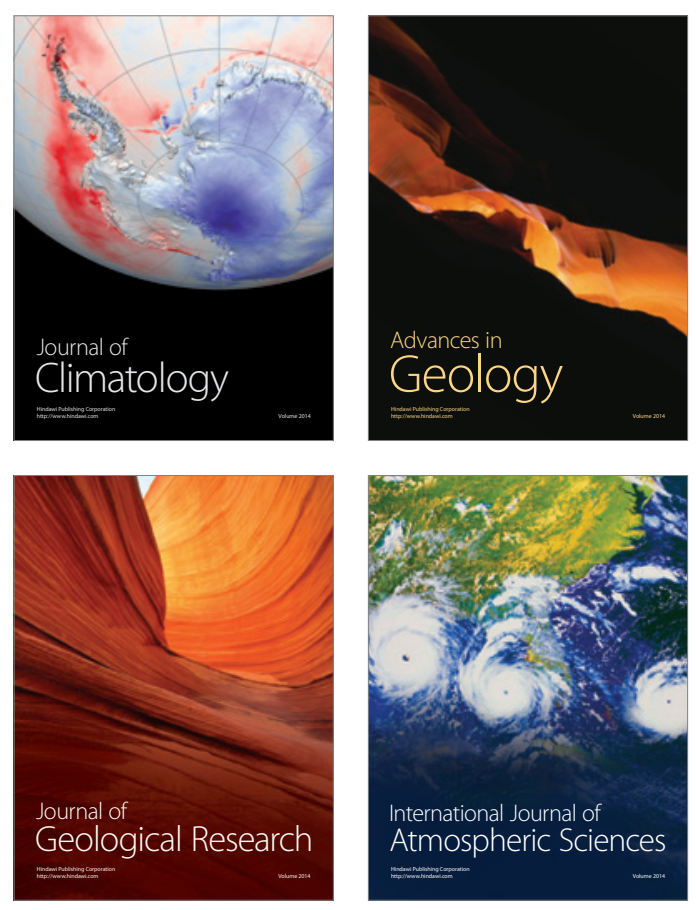
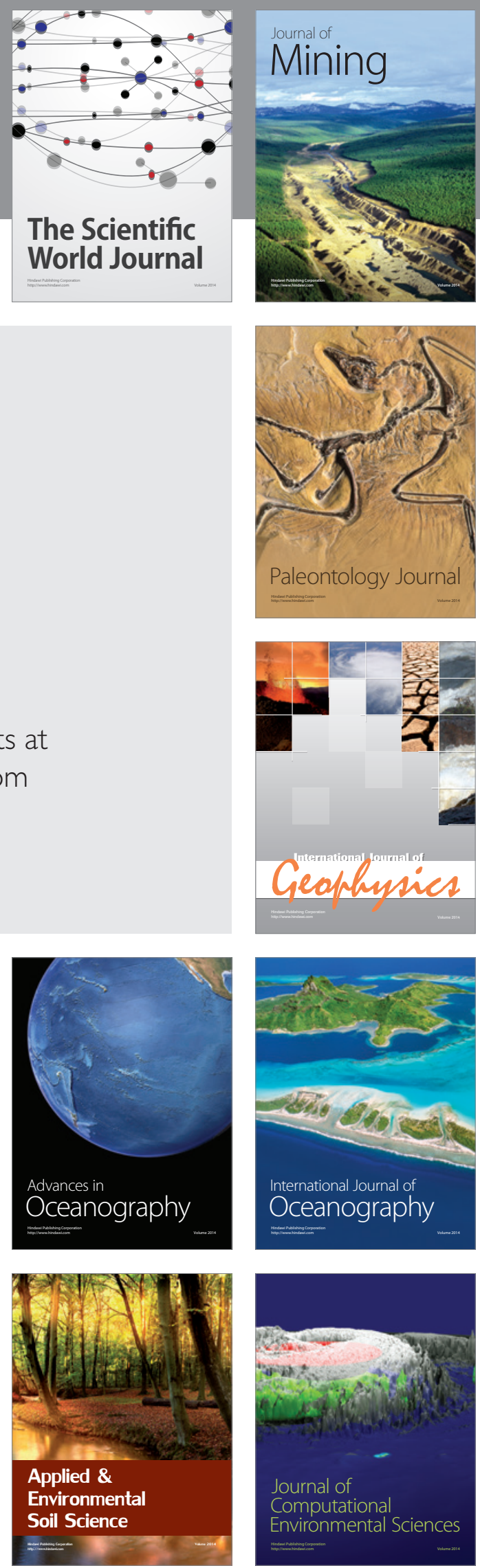